\title{
The Constitutionality of Regulating Human Genetic Engineering: Where Procreative Liberty and Equal Opportunity Collide
}

\author{
John B. Attanasio† \\ "perfection is admirable but a trifle inhuman. . ." \\ I. INTRODUCTORY Note
}

Liberty and equality probably make up the essence of American constitutional principle. ${ }^{2}$ These central aspirations of our con-

$\dagger$ Associate Professor, Notre Dame Law School; LL.M., Yale Law School; Dipl. in Law, University of Oxford; J.D., New York University School of Law; B.A., University of Virginia.

As this project has been in the works for quite some time, I can only mention some of those who generously contributed their time and wisdom. Earlier drafts were reviewed by Guido Calabresi, Stephen Carter, Donald Elliott, Thomas Emerson, Owen Fiss, Jay Katz, Myres McDougal, and Judith Thomson of the Yale Law School; Frank Ruddle of the Yale Biology Department; Welsh White of the University of Pittsburgh School of Law; Harvey Bender of the Notre Dame Biology Department; as well as Kathleen Spartana and Stefan Underhill. I also received valuable comments during presentations at Notre Dame, George Washington, and Tulane law schools.

LeRoy Walters of the Kennedy Institute of Georgetown University, Nancy Rudden of the Oxford Biology Department, and David Gauthier and Ken Schaffner of the University of Pittsburgh Philosophy Department provided critical guidance at various stages of this endeavor. Research librarians David Boeck and Michael Slinger were quite helpful, as were my research assistants, John McGeeney, Carl Livingston, and William Cowden. The Universities of Notre Dame and Pittsburgh provided generous support.

${ }^{1}$ Roger Angell, The Summer Game 41 (1972) (describing the attitude of a New York Mets fan toward the New York Yankees in 1962).

2 The opinions of the Supreme Court illuminate their centrality. The realm of liberty encompasses first amendment ideals of free speech, thought, and conscience. See, e.g., Thomas I. Emerson, The System of Freedom of Expression (1970); Philip B. Kurland, Religion and the Law (1962). It also embraces procedural due process rules that circumscribe governmental power to confine and constrain, see, e.g., Jerold Israel, Selective Incorporation: Revisited, 71 Geo. L. J. 253 (1982), and substantive due process notions that eliminate governmental regulation from certain discrete areas, see, e.g., John Hart Ely, The Supreme Court, 1977 Term-Foreword: On Discovering Fundamental Values, 92 Harv. L. Rev. 5 (1978); Kenneth L. Karst, The Freedom of Intimate Association, 89 Yale L. J. 624 (1980).

Equality appears most prominently in the jurisprudence of the equal protection clause. See, e.g., Gerald Gunther, The Supreme Court, 1971 Term-Foreword: In Search of Evolving Doctrine on a Changing Court: A Model for a Newer Equal Protection, 86 Harv. L. Rev. 1 (1972); Michael J. Perry, Modern Equal Protection: A Conceptualization and Appraisal, 79 Colum. L. Rev. 1023 (1979). 
stitutional faith often coexist in conflict. ${ }^{3}$ Theory does not demand this tension;" but unfortunate realities inject a degree of enmity between these ideals. One of these realities is prejudice, such as racism or sexism. For example, achieving some measure of racial equality in a segregated society has necessitated the impositions on liberty brought about by the remedy of forced busing. ${ }^{5}$ A second sobering condition that pits liberty against equality is disparate wealth. ${ }^{B}$ For example, the liberty to speak has been construed to allow richer candidates for office the right to outspend poorer ones. ${ }^{7}$

A third harsh reality that may exacerbate this tension is unequal natural ability. By natural ability I mean the sum of one's talents, including intelligence and capacity for hard work. ${ }^{8}$ This

${ }^{3}$ Not only does the interplay between these values spark controversy, but so does defining the content of each. For example, University of California Regents v. Bakke, 438 U.S. 265 (1978), revealed a deep rift in the Court regarding what sort of classifications offend equal protection. Compare id. at 287-99 with id. at 356-62 (Brennan, J., concurring). The concept of liberty can be similarly hard to define with precision. In McGowan v. Maryland, 366 U.S. 420 (1961), and Braunfield v. Brown, 366 U.S. 599 (1961), the Court struggled to choose between transgressing the freedom of conscience of the majority who worshiped on Sundays and that of the minority who did not. The decisions, upholding Sunday closing laws against an establishment clause challenge in McGowan and a free exercise challenge in Braunfield, illustrated a certain indeterminance as to what counts as religious liberty.

- Liberty and equality should sustain each other. Equal political power is less conducive to domination than is oligarchy; this suggests that equality nurtures liberty. Adam Smith noted that the absence of concentrated economic power favors economic liberty. Adam Smith, Lectures on Jurisprudence 83-84, 363-64, 471-72, 497-98, 529 (R. L. Meek, D. D. Raphael, and P. G. Stein eds. 1978); Adam Smith, The Wealth of Nations 278 (Edwin Cannon ed. 1976). See also Richard A. Posner, The Economics of Justice 72 (1981) (deprecating monopoly power).

s See generally Keyes v. School District No. 1, Denver, Colo., 413 U.S. 189, 247-52 (1973) (Powell, J., dissenting). In constitutional jurisprudence, combatting racism generally has resulted in equality infringing on liberty. In Bob Jones University v. United States, 461 U.S. 574 (1983), racial equality exacted a heavy toll on religious liberty. The Court upheld the government's denial of tax exempt status to a denominational university that proscribed interracial dating or marriage by students because sponsors of the University "genuinely believe[d] that the Bible forbids [those practices]." Id. at 580. In Roberts v. Jaycees, 468 U.S. 609 (1984), the Court allowed a demand for gender equality to infringe on freedom of association, upholding a Minnesota law compelling the all-male Jaycees to admit women.

- Claims of political liberty often have exacerbated preexisting economic inequality. In First National Bank of Boston v. Bellotti, 435 U.S. 765 (1978), the Court extended the right of free speech to corporations. Libertarian claims of corporate speech thus superseded individual contentions of unequal ability to speak. See generally id. at 788-92 (majority opinion), 809-12 (White, J., dissenting). See also Jerome Barron, Access to the Press-A New First Amendment Right, 80 Harv. L. Rev. 1641 (1967) (libertarian interests undergirding a free press clash with competing egalitarian claims of access to the media).

${ }^{7}$ Buckley v. Valeo, 424 U.S. 1 (1976) (per curiam). The Buckley Court struck down that part of the Federal Election Campaign Act that limited the amount a candidate could spend on his own campaign.

- Consider John Rawls, A Theory of Justice 74 (1971), in which Rawls maintains that 
condition, which is partly a quirk of fate, ${ }^{\circ}$ figures heavily-along with fortune and risk taking-in determining the distribution of resources within society. ${ }^{10}$ Government itself routinely distributes valuable resources-such as jobs and education-based on natural ability. ${ }^{11}$

Counting ability as a property right, a libertarian might argue that government should not be empowered to regulate it. In the constitutional context, Lochner $v$. New York ${ }^{12}$ and its progeny endorsed the assertion that labor, which partly manifests ability, should be enveloped in constitutional protection. The subsequent acceptance (by a judiciary under intense political pressure ${ }^{13}$ ) of extensive regulation of economic enterprise represented an egalitarian incursion on individual freedom to exploit one's natural abilities. $^{14}$ The constitutional amendment permitting taxation of income represented another egalitarian constraint on liberty. ${ }^{15}$ Thus, egalitarian concerns have substantially contracted the pro-

distributions according to effort are morally capricious because the ability to exert effort is arbitrarily distributed. Individuals may still have some claim to their exertion of effort on the ground that to deny them any such claim would amount to involuntary servitude. Society.might also recognize such claims, on utilitarian grounds, to give incentives to exert effort.

- See id. at 15, 103-04.

10 See President's Commission for the Study of Ethical Problems in Medicine and Biomedical and Behaviorial Research, Splicing Life: A Report of the Social and Ethical Issues of Genetic Engineering with Human Beings 67-68 (1982) ("President's Commission"); Rawls, A Theory of Justice at 93 (cited in note 8) (listing intelligence, wealth, and opportunity as primary social goods that allow persons to attain their personal goals); Michael Shapiro, Who Merits Merit? Problems in Distributive Justice and Utility Posed by the New Biology, 48 So. Cal. L. Rev. 318, 347 (1974); Note, Eugenic Artificial Insemination: A Cure for Mediocrity?, 94 Harv. L. Rev. 1850, 1862 n.59 (1981). The Supreme Court does not shield people from a distributive standard based on natural ability. See generally Note, Equal Protection and Intelligence Classifications, 26 Stan. L. Rev. 647 (1974). The primary attempt that society makes to redress superior ability that results in superior wealth is to tax income and inheritance progressively. 26 U.S.C. \$§ 1-1564, 2001-09 (1982 \& Supp. 1985).

11 The Constitution helps to underwrite the economic value of differential ability by protecting private property, even when it is acquired as a result of differential ability. See, e.g., U.S. Const. amend. V (proscribing governmental takings of property without just compensation).

12198 U.S. 45 (1905).

13 See Robert Jackson, The Struggle for Judicial Supremacy (1941); Merto Pussey, The Supreme Court Crisis (1937).

14 In this connection, obvious distributive effects emanated from labor decisions upholding statutes which enforce minimum wages, maximum hours, and collective bargaining. See generally United States v. Darby, 312 U.S. 100 (1941); Labor Board v. Jones \& Laughlin Steel Corp., 301 U.S. 1, 33-34 (1937).

15 U.S. Const. amend. XVI. The sixteenth amendment was necessitated by the Supreme Court's decision in Pollock v. Farmers' Loan \& Trust Co., which held the Income Tax Act of 1894 unconstitutional, 157 U.S. 429 (1895), on reh'g, 158 U.S. 601 (1895). 
tective ring of individual liberty. A more circumscribed sphere remains that includes freedom of thought, belief, and expression; freedom from arbitrary search, seizure, confinement, or punishment; and freedom in childbearing, ${ }^{16}$ child rearing, ${ }^{17}$ and certain other familial matters. ${ }^{18}$

\section{A. Human Genetic Engineering: The Genos Scenario}

Suppose government intruded on the personal sphere to regulate for egalitarian ends the distribution of abilities, that is, the "constitution" of the human being itself. Such is the prospect presented by positive genetic engineering, ${ }^{19}$ which seeks to augment the biological capabilities of human beings. To focus the inquiry, the following scenario pits egalitarian interests in race, wealth, and ability against libertarian interests in childbearing and child rearing.

16 See, e.g., Roe v. Wade, 410 U.S. 113, 152-56 (1973); id. at 168-70 (Stewart, J., concurring).

${ }_{17}$ See, e.g., Pierce v. Society of Sisters, 268 U.S. 510, 534-35 (1925) (right of parents to send children to private schools).

18 See, e.g., Moore v. City of East Cleveland, 431 U.S. 494, 499 (1977) (striking down zoning ordinance prohibiting "extended family" from living together in single dwelling unit).

10 The term "genetic engineering" has been used in both a narrow and a broad sense. Narrowly, it refers to a "wide range of techniques by which scientists can add genetically determined characteristics to cells which would not otherwise have possessed them." President's Commission at 8 (cited in note 10). One such technique utilizes deoxyribonucleic acid (DNA), which encodes and passes on genetic characteristics. Since DNA's discovery in 1953, scientists have learned how to isolate a specific DNA sequence from one species or organism and transfer it to a second species or organism to alter that second species or organism. This process is called "recombinant DNA." Id. at 9. A related technique involves cell fusion, which brings together genetic material from two cells to produce a hybrid that can reproduce. Id.

In a broader sense, genetic engineering may refer to selective breeding, in vitro fertilization, cloning, and even the practice of medicine. Id. Although the specific hypothetical situation that this article addresses primarily involves genetic engineering in the narrow sense, I also use the term more broadly to encompass any purposeful alteration of an organism's genetic composition. In addition to recombinant DNA and cell fusion, this definition would include cloning, breeding superior traits, in vitro fertilization when used in breeding, and sterilization to alter the genetic composition of the species. The definition would exclude in vitro fertilization used to assist a woman with blocked fallopian tubes. Id. at 9 . It would also exclude the ordinary practice of medicine that happens to change the genetic characteristics of the human race by allowing those who have life-threatening genetic deformities to survive and reproduce those deformities. Id. at 8.

Genetic engineering often is classified as negative or positive. The negative sort reduces or eliminates deleterious genes while the positive type encourages desirable or superior traits. See generally Louis van Loon, A Buddhist Perspective, in G. Oosthuizen, H. Shapiro, and S. Strauss, eds., Genetics and Society 148, 154-55 (1980). Of course, the two categories overlap. Id. at 155 . Although parts of this article treat problems in negative genetic engineering, the focus is on the positive sort. 
Suppose a drug company discovers a new drug, Genos, ${ }^{20}$ which can be used to develop stronger, more intelligent human beings. The method of using the drug involves a series of complex surgical procedures. Researchers begin by extracting an egg from a woman and fertilizing it in vitro. They proceed through micro-injection to manipulate pharmacologically the genetic structure of the fertilized egg. The egg is then inserted back into the womb where it develops until the woman gives birth.

Suppose the drug company has performed these operations, on an experimental basis, on human beings of various racial and ethnic extractions, in various environmental conditions. Subjects of the Genos experiments have been many times stronger - in both strength and stamina - than average human beings of their sex, and have had IQs ${ }^{21}$ well above genius level. Although the drug helps to foster societal standards of beauty, its human subjects have also exhibited several physical characteristics that make them easily recognizable. ${ }^{22}$ Otherwise, it is undisputed that the drug is completely safe to use and poses no undesirable side effects to the mother or to the resulting fetus ${ }^{23}$ or child at any stage of development. ${ }^{24}$

Finally, suppose scarcity of the raw materials necessary to manufacture the drug will limit Genos births to approximately 15,000 per year. Based on natural scarcity, high production costs, and high surgical costs, the drug company estimates that the price of having a Genos child will be $\$ 170,000{ }^{25}$ The paucity of raw materials needed to produce Genos will increase the price of the drug for the foreseeable future. Under pressure from citizens who cannot afford the drug, Congress considers the policy merits and constitutionality of a ban on the manufacture of Genos. ${ }^{26}$

20 "Genos" is a Greek word that means "birth, race, kind, stock, genus." 4 Oxford English Dictionary 123 (1933). See also Henry George Liddell and Robert Scott, eds., A GreekEnglish Lexicon 344 (1940).

${ }^{21}$ I use IQ simply to indicate that the drug dramatically increases intelligence, however measured.

${ }^{22}$ Some genetic techniques, like the use of growth hormone, produce distinctive physical characteristics. See sources cited in note 38 below.

${ }^{23}$ Throughout this article, I will use "fetus" to refer to all stages of prenatal development from the fertilized egg forward. This usage is partly for simplicity and partly because genetic engineering might take place at various stages of prenatal development.

24 The projection does not consider safety risks, as these are specific to individual genetic technologies. below.

${ }^{25}$ Genos would generate difficult issues even if it were not expensive. See note 272

${ }^{28}$ The regulation of Genos controls morality and lifestyle, areas traditionally covered by the regulation regimes of the states. See, e.g., Gibbons v. Ogden, 22 U.S. 1, 203 (1824). 
Is this situation wildly improbable? Science is not yet capable of genetic engineering on the scale described in the above scenario, which is unabashedly futuristic for two reasons. First, it is hard to know exactly how far science has progressed. The furious pace of experimentation is geometrically expanding our understanding of genetic processes. Moreover, strong incentives exist to keep advances secret: much genetic research is controversial, ${ }^{27}$ and often the maintenance of trade secrets is all that protects financial bonanzas. ${ }^{28}$ In this milieu, focusing on the present state of knowledge renders legal analysis obsolete as soon as pen is put to paper. Alternatively, waiting to discuss regulation until these technologies are operational is pointless: by that time events will dictate legal rules.

Somewhat paradoxically, the second reason the scenario is futuristic is that, by traveling far beyond known scientific capabilities, it provides a starting point for analysis. The only feasible method of considering policy options may be to anticipate the eventual results of current research. ${ }^{29}$ By focusing on an extreme

Thus, in order to fall within Congress's regulatory ambit, controls on the drug might need to be characterized as regulations of commerce. Current judicial constructions of the commerce power are certainly broad enough to permit Congress to claim that Genos has a substantial effect on interstate commerce. See, e.g., FERC v. Mississippi, 456 U.S. 742, 756-58 (1982) (applying test of whether there is "rational basis" to connect regulation with interstate commerce); EEOC v. Wyoming, 460 U.S. 226, 246-48 (1983) (Stevens, J., concurring) (upholding prohibition on age discrimination as within commerce power); Katzenbach v. McClung, 379 U.S. 294, 302 (1964) (upholding prohibition on discrimination in accommodations as within commerce power). Nor would regulation-even proscription-violate the economic rights of the drug's vendors under the due process or equal protection clauses. See, e.g., Williamson v. Lee Optical Co., 348 U.S. 483, 488-89 (1955). Products like Genos illustrate how fundamentally economic regulations can affect personal liberty, as the Court conceives of it. Genos further blurs the line between congressional regulation of economic liberty and court protection of personal liberty.

${ }^{27}$ See, e.g., Keith Schneider, Release of a Gene-Altered Agent Violated Policy, E.P.A. Charges, N.Y. Times, Feb. 27, 1986, at B28, col. 1 (release of first genetically engineered organisms into the atmosphere performed without public or governmental knowledge).

${ }^{28}$ The United States Department of Commerce recently estimated that the worldwide market for genetically engineered drugs alone could reach $\$ 100$ billion per year by the year 2000. Peter Osterfund, Challenges to U.S. Lead in Biotech, Christian Science Monitor, Jan. 24,1985 , at 14 , col. 1 .

20 The New York Times called human genetic engineering "a watershed in history, perhaps in evolution" and urged that debate concerning these technologies begin now. Whether to Make Perfect Humans, N.Y. Times, July 22, 1982, at A22, col. 1. Senator Albert Gore, who chaired the recent congressional committee on human genetic engineering, urged that society begin to establish guidelines now because "the technology to perform gene therapy may be upon us sooner than originally imagined." Albert Gore and Steve Owens, The Challenge of Biotechnology, 3 Yale L. \& Pol'y Rev. 336, 354 (1985). Senator Gore continued:

The first gene therapy experiments could occur within a year. Although these experiments will entail only an elementary application of the technology, they represent the 
form of positive human genetic engineering, we can ponder whether government can or should prohibit any safe forms of positive genetic manipulation. ${ }^{30}$ The basic inquiry lays a foundation upon which to build future analyses addressing specific technologies. To merit serious consideration, however, our scenario must have some basis in reality.

In this connection, several technologies lend credibility to the prospects of something like Genos. Perhaps the simplest technology that might be used to develop genetically superior traits combines artificial insemination with heredity. The number of children born who are conceived by artificial insemination now exceeds 20,000 per year. ${ }^{31}$ Sperm donors can be selected for genetically attractive traits. Indeed, one wealthy eugenicist has embarked on a program of genius sperm banks: the sperm of Nobel Laureates and other highly intelligent individuals have been used artificially to inseminate recipients who are also selected for their high intelligence. ${ }^{32}$ In vitro fertilization techniques expand the possibilities by permitting eggs to be removed from women with particularly high intelligence or other desired traits. ${ }^{33}$ After the egg is fertilized in vitro by the sperm of a donor with desirable traits, the resultant embryo may be inserted into a womb donor and sold ${ }^{34}$ or "donated" at birth—or perhaps while still in the womb. ${ }^{35}$ In vitro

first step on a journey to an unknown destination. The earlier in the journey that society develops guidelines for dealing with gene therapy, the smoother the trip will be. Id. at 354-55.

so The Food and Drug Administration (FDA) must approve all drugs in interstate commerce for safety and efficacy. See 21 U.S.C. $\$ \S 331,355$ (1982). See Wallace Janssen, The U.S. Food and Drug Law: How It Came About; How It Works, 35 Food Drug Cosmetic L. J. 132, 137-38 (1980).

31 Note, Genesis Retold: Legal Issues Raised by the Cryopreservation of Preimplantation Human Embryos, 36 Syracuse L. Rev. 1021, 1022 (1985).

${ }^{32}$ Note, 94 Harv. L. Rev. at 1850 \& nn. 4-5 (cited in note 10). Beyond potential application of laws against adultery and fornication, the practice of artificial insemination is now virtually unrestricted. Kathryn Lorio, Alternative Means of Reproduction: Virgin Territory for Legislation, 44 La. L. Rev. 1641, 1645-53 (1984); Note, 94 Harv. L. Rev. at 1855 (cited in note 10); Comment, The Need for Regulation of Artificial Insemination by Donor, 22 San Diego L. Rev. 1193, 1196 (1985).

${ }^{33}$ The federal government has studied the implications of in vitro fertilization. Ethics Advisory Board Report and Conclusions: New Support of Research Involving In Vitro Fertilization and Embryo Transfer, 44 Fed. Reg. 35,033, 35,041 (1979).

34 However, many states forbid commercial trafficking in babies. See Lorio, $44 \mathrm{La}$. L. Rev. at 1657-58 (cited in note 32). Definitional issues would be crucial to the legality of the sale of an embryo or fetus. For a discussion of embryo transactions as they relate to procreative liberty, see John A. Robertson, Embryos, Families, and Procreative Liberty: The Legal Structure of the New Reproduction, 59 So. Cal. L. Rev. 939, 1018-21 (1986).

${ }^{35}$ Critics may doubt the effectiveness of these techniques and point out that intelligence and other desirable traits are determined by environment as well as by heredity. 
fertilization alone is expensive. Several attempts are normally required, and costs can vary from $\$ 5,000$ to $\$ 25,000 .^{36}$ Sperm or eggs from persons with desired traits could also fetch considerable sums.

Beyond the use of heredity, science currently has pharmacological and other means of fostering superior traits. Certain drugs may be able significantly to increase memory and $\mathrm{IQ} .{ }^{37}$ Growth hormone, which has been used to augment the stature of dwarfs, can stretch size and potential immediate strength. ${ }^{38}$ Technology can also manipulate stamina. For example, scientists have implanted electrodes into the brain that might be used to generate desired responses to effect attitudinal changes such as increased productivity. ${ }^{39}$

Further, abortion may be used to foster desirable genetic traits. Although there is no necessary link between genetic characteristics and abortion, amniocentesis and other technologies enable doctors to examine the genetic makeup of the fetus. Current capabilities largely are confined to the realm of negative genetic engineering, that is, to spotting and aborting fetuses with genetic defects. But it may also be possible to foster desired traits: parents

Many studies, however, indicate that the influence of heredity on intelligence may be fairly significant. See Sandra Scarr and Louise Carter-Saltzman, Genetics and Intelligence, in John Fuller and Edward Simmel, eds., Behavior Genetics 217, 264-76, 317-18 (1983). See also Note, 94 Harv. L. Rev. at 1856 n.34 (cited in note 10) (citing studies that also highly correlate intelligence with heredity). To the extent that intelligence is influenced by environment, it can also be controlled. Parenthetically, several studies indicate that grossly disadvantageous environments together with cultural biases in intelligence tests discount the strength of this heredity-intelligence correlation in the case of black persons. Sandra Scarr and Louis Carter-Saltzman, Genetics and Intelligence, in John Fuller and Edward Simmel, eds., Behavior Genetics at 300 (1983).

${ }^{36}$ William J. Winslade and Judith Wilson Ross, High-Tech Babies: A Growth Industry, N.Y. Times, Feb. 21, 1986, at A31, col. 2.

${ }^{37}$ Shapiro, 48 So. Cal. L. Rev. at $319 \mathrm{n} .1$ (cited in note 10). One technique involves pharmacologically increasing the supply of RNA, which is DNA's genetic messenger and also governs cell metabolism. Roderic Gorney, The New Biology and the Future of Man, 15 U.C.L.A. L. Rev. 273, 350 (1968).

ss Indeed, the growth hormone can now be synthetically produced using recombinant DNA techniques. Stuart L. Nightingale, Emerging Technologies and FDA Policy Formulation: The Impact of Government Regulation on Developing Drugs from New Technologies, 37 Food Drug Cosmetic L. J. 212, 215 (1982). Widespread use of the hormone remains circumscribed because it causes undesirable disproportions in body parts. Human Genetic Engineering: Hearings Before the Subcomm. on Investigations and Oversight of the House Comm. on Science and Technology, 97th Cong., 2d Sess. 225 (1982) (testimony of Zsolt Harsanyi, Vice-President, DNA Sciences, E. F. Hutton) ("Hearings").

30 Gorney, 15 U.C.L.A. L. Rev. at 338-41 (cited in note 37). See also John Batt, They Shoot Horses, Don't They?: An Essay on the Scotoma of One-Eyed Kings, 15 U.C.L.A. L. Rev. 510, 523-25 (1968). 
already may determine their child's gender. ${ }^{40}$ As the prognostic vision of science grows more acute, technology will permit fertilizing several eggs at a time in vitro and then aborting all but the most desirable embryo.

On the horizon lie the techniques of cloning and gene splicing, by which one can replicate or rearrange the genetic structure of a particular individual. Cloning is a technology capable of producing an offspring that is an exact genetic likeness of the parent organism. Generally speaking, the nucleus of the cell or the organism that is to be replicated is substituted for the nucleus of an egg cell. ${ }^{41}$ Although the process has never been performed successfully on humans, frogs were first cloned over a decade ago, ${ }^{42}$ and mice have been duplicated by similar methods. ${ }^{43}$ Applied to people, cloning could develop superior genetic traits by copying human beings who have them. Alternatively, selective mating could breed "model human beings" to clone.

Perhaps the most far-reaching genetic technology is gene splicing, or recombinant DNA. The genetic structure of the cell resembles a chain of genes. Recombinant-DNA technologies splice that chain to rearrange it or substitute new genetic matter in order to alter the genetic composition of the cell. ${ }^{44}$ These technologies already have myriad commercial and medical applications, primarily involving plants and microorganisms. ${ }^{45}$ The state of the art has progressed far beyond this stage, however-perhaps to the creation of a new "superspecies" of animals. ${ }^{46}$

10 See Note, Sex Selection Abortion: A Constitutional Analysis of the Abortion Liberty and a Person's Right to Know, 56 Ind. L. J. 281, 283-84 (1981) (arguing that the legislature can constitutionally proscribe discriminatory abortion for gender selection).

41 Environmental differences will cause parent and clone to be less than exactly identical. See George Huddock, Gene Therapy and Genetic Engineering: Frankenstein Is Still a Myth, But It Should Be Reread Periodically, 48 Ind. L. J. 533, 555-56 (1973).

12 Clifford Grobstein, From Chance to Purpose: An Appraisal of External Human Fertilization 126 (1981).

ts The techniques that have been used to clone mice are somewhat different from those used to clone frogs. Cloning has also produced identical calf twins. See Burke Zimmerman, Biofuture 270-71 (1984).

4 See note 19 above.

15 Office of Technology Assessment, U.S. Cong., Commercial Biotechnology: An International Analysis (1984); President's Commission at 9, 36-38 (cited in note 10); Edward Korwek, FDA Regulation of Biotechnology as a New Method of Manufacture, 37 Food Drug Cosmetic L. J. 289, 291-92 (1982); Thomas McGarity and Karl Bayer, Federal Regulation of Emerging Genetic Technologies, 36 Vand. L. Rev. 461, 465 (1983).

"An important breakthrough was the creation of "supermice" in 1982 through the injection of rat growth genes into mouse embryos, producing mice roughly twice normal size. See, e.g., Jeffrey G. Williams, Mouse and Supermouse, 300 Nature 575 (1982); Jon W. Gordon and Frank H. Ruddle, Gene Transfer into Mouse Embryos: Production of Trans- 
Genetic structure plays some role in influencing virtually every aspect of human development, including such traits as body weight, height, hair color, eye color, intelligence, disease resistance, and perhaps even personality and longevity. ${ }^{47}$ But applying recombinant-DNA technologies to engender positive traits in human beings seems beyond our grasp for the present. Particularly difficult will be influencing the complex, polygenic trait of intelligence. ${ }^{48}$ Still, in recent congressional hearings, several prominent physicians cautioned that society now should begin pondering even this technological advancement. ${ }^{49}$ In vitro fertilization now allows the manipulation of the egg and young embryo outside the womb. ${ }^{\text {so }}$ Scientists already have developed systems by which they have successfully injected new genetic material into cells. ${ }^{51} \mathrm{By}$ the end of

genic Mice by Pronuclear Injection, 101 Methods in Enzymology 411 (1983). Essentially, a new species was born. Supermice have also been fabricated using synthesized human growth hormone genes. See generally Maxine Singer, Genetics and the Law: A Scientist's View, 3 Yale L. \& Pol'y Rev. 315, 330 (1985). Recently, the United States Department of Agriculture funded attempts to create "supersheep" and "superpigs." One of the researchers who fashioned the supermice is attempting to apply the technology to sheep and pigs, using synthesized human growth genes. 50 Fed. Reg. 9760 (1985). Crossing species has generated controversy. See Singer, 3 Yale L. \& Pol'y Rev. at 328-30 (cited in this note); Jeremy Rifkin, Algeny 10 (1983).

${ }^{47}$ See Zimmerman, Biofuture at 51-62 (cited in note 43); Lee Ehrman and Joan Probber, Fundamentals of Genetic and Evolutionary Theories, in Fuller and Simmel, eds., Behavior Genetics at 21 (cited in note 35). See also Grobstein, From Chance to Purpose at 125 (cited in note 42).

48 Compare Zimmerman, Biofuture at 192 (cited in note 43) (predicting that time for direct manipulation of traits like intelligence "probably won't be as much as 50 years and could be as short as 10") with Grobstein, From Chance to Purpose at 125 (cited in note 42) (discounting the possibility of genetically manipulating intelligence, strength, or beauty for the foreseeable future). See also President's Commission at 33-34 (cited in note 10).

40 Hearings at 226-33 (cited in note 38) (testimony of Zsolt Harsanyi, Vice-President, DNA Sciences, E.F. Hutton), 289-92 (testimony of W. French Anderson, Chief, Molecular Hematology Lab., National Heart, Lung and Blood Institute), 289 (testimony of Mark Skolnick, Professor of Medical Genetics, Univ. of Utah College of Medicine), 295 (testimony of Theodore Friedman, Professor of Pediatrics, Univ. of California School of Medicine), 476 (testimony of Liebe Cavalieri, Professor of Biochemistry, Cornell Medical College).

so Id. at 473 (testimony of Liebe Cavalieri, Professor of Biochemistry, Cornell Medical College).

Recent medical advances in the treatment of the fetus have been nothing short of fantastic. Administering certain drugs to the mother may prevent or minimize respiratory distress at birth. Patricia King, The Juridical Status of the Fetus: A Proposal for Legal Protection of the Unborn, 77 Mich. L. Rev. 1647, 1675 (1979). Blood transfusions can now be administered to the fetus in utero. Id. Drugs also can be surgically administered directly to the fetus through fetoscopy. Doctors can observe the fetus throughout the pregnancy to diagnose diseases and can even remove it temporarily for treatment. John A. Robertson, Procreative Liberty and the Control of Conception, Pregnancy, and Childbirth, $69 \mathrm{Va}$. L. Rev. 405, 407 (1983); King, 77 Mich. L. Rev. at $1676 \mathrm{n} .137$ (cited in this note) (experiments removing primates from the womb for treatment and replacing them for delivery at term).

${ }^{51}$ Zimmerman, Biofuture at 273-74 (cited in note 43). See also Hearings at 193-96 
the decade, science will likely have charted the entire genetic makeup of some multicellular species. In less than ten years, we may have a complete map of our entire genetic code. ${ }^{52}$

The genetic age is upon us. The metamorphosis has been likened to nuclear fission. ${ }^{33}$ While all living matter will be affected, refashioning the human organism in particular raises uniquely profound legal and ethical questions.

\section{B. The Dialogue}

This article probes the constitutionality-and policy merits-of regulating positive genetic engineering. As the title indicates, such restrictions may precipitate a collision between the constitutional values of procreative liberty and equal opportunity. Other libertarian and egalitarian values also are implicated. The enormity and complexity of the issues requires that goals, inquiries, and methodologies be modest. My goals in this article are to spark discussion of emerging reproductive technologies and to provide an analytical framework for further study. As already noted, the narrow query to be addressed is whether government can or should ban extreme but safe forms of positive genetic engineering. The method will be to question rather than to answer. Consequently, the article will be cast as a dialogue, illuminating libertarian and egalitarian perspectives on these developments.

The dialogue first will explore whether a congressional ban on Genos would violate the liberty interests, in childbearing and child rearing, of persons who wish to have Genos children. It then will explore how such a ban might affect the liberty interests of the fetus. Assuming that prohibiting Genos impairs some liberty claim, the discussion will probe whether the ban serves compelling egalitarian interests asserted on behalf of Genos people or non-Genos people. In this regard, it will explore whether traditional equal protection jurisprudence guarantees the rights of a genetically superior minority or of a genetically inferior majority. This part of the dialogue also will discuss how Genos affects equality of condition under the nobility clauses and the prohibition against slavery. Fi-

(cited in note 38) (testimony of Richard Axel, Professor of Biochemistry and Pathology, Columbia Univ.), 207-08 (testimony of Barbara Sanford, Director, Jackson Lab.).

${ }^{82}$ Marc Lappe, Broken Code: The Exploitation of DNA 36 (1984).

${ }^{53}$ Nicholas Wade, The Ultimate Experiment: Man-Made Evolution 2 (1977). Appropriate to the nuclear fission analogy, genetically engineered substances can be deployed in biological warfare. Yvonne Cripps, A New Frontier for International Law, 29 Int'l Comp. L. Q. $1,9(1980)$. 
nally, it will consider how Congress may formulate new egalitarian interests using section five of the fourteenth amendment or section two of the thirteenth amendment.

After exploring the conflict between liberty and equality that may result from controls on genetic engineering, the dialogue will seek a resolution of the conflict. It will consider whether an absolute ban is necessary in order to respect egalitarian interests or whether alternative schemes for distributing Genos will sufficiently mitigate egalitarian concerns.

Finally, the discourse will consider a philosophical resolution of the constitutional conflict. It will examine the libertarian paradigm of Robert Nozick, the egalitarian perspective of Bruce Ackerman, and the attempted liberty-equality synthesis of John Rawls. The conclusion will ponder the implications of the analysis for the future of human genetic engineering.

In the ensuing dialogue, the libertarian position favoring $\mathrm{Ge}-$ nos will be denominated by the Latin word LIBERTAS; ${ }^{54}$ the egalitarian position against the drug, by the Latin word AEQUUS. ${ }^{55} \mathrm{I}$ will try to illuminate the strongest arguments for each side.

\section{The Constitutional Analysis}

A. The Liberty to Bear and Rear Genetically Superior Children

1. Is there an Analogy between Genos and the Rights to Contraception and Abortion?

a.) Is procreative liberty a fundamental right?

LIBERTAS: The fundamental right to procreative liberty guarantees parental choice to bear children whose traits are enhanced by positive genetic engineering. The Supreme Court has erected generous protections around the childbearing prerogative. Not only has it clothed decisions regarding contraception ${ }^{56}$ and abortion $^{57}$ with constitutional protection, but it has resisted intrusions on this enclave by some powerful countervailing interests. With respect to contraception, it has extended this guarantee to

s4 Translated from Latin, libertas means "the state or condition of a freeman, a being free, freedom, liberty, freedom from restraint or obligation, free will." Harpers' Latin Dictionary 1058-59 (Charlton T. Lewis and Charles Short eds. 1907).

Bs Translated from Latin, aequus means "[t]hat is equal to another in any quality, equal, like." Id. at 57.

ss Griswold v. Connecticut, 381 U.S. 479, 485 (1965).

${ }^{37}$ Roe, 410 U.S. at 162-64. 
the unmarried ${ }^{58}$ and perhaps to minors. ${ }^{59}$ The right of abortion has been encased in an even stronger constitutional shield. The Court has proscribed a consent form designed to dissuade a woman from having an abortion ${ }^{60}$ and a twenty-four hour waiting period between signing an abortion consent form and undergoing the procedure. ${ }^{61}$ The Court has also barred criminal liability for abortions based on a doctor's erroneous determination of viability made in good faith. ${ }^{62}$

As the Supreme Court made clear in Maher v. Roe, ${ }^{63}$ the protection of childbearing extends beyond the right to have an abortion:

A woman has at least an equal right to choose to carry her fetus to term as to choose to abort it. Indeed, the right of procreation without state interference has long been recognized as "one of the basic civil rights of man . . . fundamental to the very existence and survival of the race."

This passage suggests two reasons for safeguarding procreative liberty in the context of genetic engineering. First, one can intuitively

${ }^{s 8}$ Eisenstadt v. Baird, 405 U.S. 438, 453 (1972).

s9 Carey v. Population Services International, 431 U.S. 678 (1977). Justice Brennan, joined by three other members of the Court, asserted that minors have some right to freedom of choice in sexual activities. Id. at 693-94. Avoiding any such implication in their decisions, three concurring Justices stated that they would allow the state considerable latitude to prohibit minors to engage in sexual activities or to use contraceptives. Id. at 702 (White, J., concurring), 703 (Powell, J., concurring), 713 (Stevens, J., concurring).

${ }^{60}$ Akron v. Akron Center for Reproductive Health, Inc., 462 U.S. 416, 444-45 (1983).

61 Id. at 450. Disregarding competing parental interests in child rearing, the Court has extended the right of abortion to minors, has virtually abrogated the requirement of parental consent, and has hotly debated whether the minor's parents even have the right to be informed of an impending abortion. H.L. v. Matheson, 450 U.S. 398, 407-10 (1981); id. at 449-53 (Marshall, J., dissenting); Planned Parenthood of Missouri v. Danforth, 428 U.S. 52, 72-75 (1976); id. at 94-95 (White, J., dissenting).

The vigor with which the Court still protects the right to an abortion was shown in the 1985 term in Thornburgh v. American College of Obstetricians, $106 \mathrm{~S}$. Ct. 2169 (1986). In Thornburgh, the Court sidestepped obstacles to appellate jurisdiction in striking down on the merits a state abortion law which included provisions requiring that the mother be given information about alternatives to abortion. The Court said: "The states are not free, under the guise of protecting maternal health or potential life, to intimidate women into continuing pregnancies." Id. at 2178.

62 See Colautti v. Franklin, 439 U.S. 379, 394-95 (1979).

63 432 U.S. 464 (1977).

of Id. at 472 n.7 (1977), quoting Skinner v. Oklahoma, 316 U.S. 535, 541 (1942). However, the holding of Maher was that a state was not obligated to provide funds for abortions to women who otherwise could not afford them. The analogous holding that the right to an abortion does not entail a right to federal funding of abortions is Harris v. McRae, 448 U.S. 297 (1980), upholding the Hyde Amendment, which prohibited federal funding even for abortions necessary to preserve the mother's health. 
justify protection of this fundamentally private decision as an essential component of human dignity. Second, permitting positive genetic engineering-through abortion or other methods-can be seen as a socially useful method of improving the species. Evolution through selection in reproduction has from at least the time of Plato been seen as both good and natural. ${ }^{\circ 5}$ Given the extensive constitutional protections already afforded procreative liberty, approval of this practice would not require a dramatic expansion of constitutional safeguards.

AEQUUS: The line of cases relating to abortion represent an unauthorized exercise of judicial power not resting upon any identifiable value embodied in the Constitution. ${ }^{86}$ But conceding that current constitutional doctrine encompasses childbearing rights, these rights still do not protect Genos. In etching the contours of these rights, the Court, in Roe $v$. Wade, ${ }^{67}$ declared:

[O]nly personal rights that can be deemed "fundamental" or "implicit in the concept of ordered liberty," . . . are included in [the] guarantee of personal privacy. [Earlier decisions] also make it clear that the right has some extension to activities relating to marriage, . . . procreation, . . . contraception, . . . family relationships . . ., and child rearing and education. ${ }^{68}$

So the Court itself admits that the protected sphere of liberty does not include all childbearing activity. Perhaps perceiving the weakness in justifying the right to abortion purely on the basis of procreative autonomy, some commentators have attempted to justify the right to abortion on other grounds such as the imperfect technology of contraception, ${ }^{69}$ gender inequality in sexual freedom, ${ }^{70}$ and the mental and physical obligations of birth imposed by the

os See Martin P. Golding, Ethical Issues in Biological Engineering, 15 U.C.L.A. L. Rev. 443,471 (1968). See also Robertson, $69 \mathrm{Va}$. L. Rev. at 410 (cited in note 50).

ss See generally John Hart Ely, The Wages of Crying Wolf: A Comment on Roe $v$. Wade, 82 Yale L. J. 920 (1973). See also John B. Attanasio, Everyman's Constitutional Law: A Theory of the Power of Judicial Review, 72 Geo. L. J. 1665, 1690 (1984) (arguing that the abortion decisions are not justified by the functional rationale the Supreme Court uses to legitimate its countermajoritarian power).

67410 U.S. 113 (1973).

68 Id. at 152-53 (emphasis added and citations omitted). For a discussion of this passage, see Note, Choosing for Children: Adjudicating Medical Care Disputes Between Parents and the State, 58 N.Y.U. L. Rev. 157, 179 (1983).

65 See Bruce A. Ackerman, Social Justice in the Liberal State 127 (1980); Donald Regan, Rewriting Roe v. Wade, 77 Mich. L. Rev. 1569, 1594 (1979).

${ }^{70}$ See Sylvia Law, Rethinking Sex and the Constitution, 132 U. Pa. L. Rev. 955, 100809 (1984); Note, The Creation of Fetal Rights: Conflicts with Women's Constitutional Rights to Liberty, Privacy, and Equal Protection, 95 Yale L. J. 599, 620-25 (1986). 
fetus. ${ }^{71}$ Without addressing whether these arguments buttress the right to abortion, they certainly do not justify a right to use Genos.

To the extent that fundamental rights decisions rest on notions of tradition, the Court will find it difficult to find a place for the chemical manipulation of genetic structure in this jurisprudential method. ${ }^{22}$ The Court should not embroil itself more deeply than it already has in the fast developing realm of medical science. In her dissent in Akron v. Akron Center for Reproductive Health, Inc. ${ }^{73}$ Justice O'Connor posed the dilemma:

The Roe framework, then, is clearly on a collision course with itself. As the medical risks of various abortion procedures decrease, the point at which the State may regulate for reasons of maternal health is moved further forward to actual childbirth. As medical science becomes better able to provide for the separate existence of the fetus, the point of viability is moved further back toward conception. ${ }^{74}$

While grappling with emerging medical technology is to some degree inescapable, the Court should proceed with caution-particularly in formulating broad-ranging, societal decisions. In fact, Genos does not affect the individual's freedom to decide whether to beget or bear a child as guaranteed by Roe. Rather, it deeply implicates choosing the type of society in which we shall live: Genos may create a master race. Constitutionally protecting its use essentially enacts a heightened form of "Mr. Herbert Spencer's Social Statics."7s

b.) Do notions of tradition justify constitutional protection for new reproductive technologies?

LIBERTAS: Myriad traditions of this nation sustain the right to use Genos. Among these are the privacy of parental decisions regarding reproduction ${ }^{76}$ and the privacy of the physician-patient relationship. ${ }^{77}$

The right to use Genos is related to historically protected procreative decisions. Reproductive technologies from birth control to

${ }^{21}$ See also Regan, 77 Mich. L. Rev. at 1639, 1645 (cited in note 69).

72 See Note, 94 Harv. L. Rev. at 1868 (cited in note 10 ).

23462 U.S. 416 (1983).

74462 U.S. at 458 (O'Connor, J., dissenting). But see Nancy K. Rhoden, Trimesters and Technology: Revamping Roe v. Wade, 95 Yale L. J. 639 (1986) (contesting the implications of Justice O'Connor's opinion).

${ }^{75}$ See Lochner v. New York, 198 U.S. 45, 75 (1905) (Holmes, J., dissenting); 15 International Encyclopedia of the Social Sciences 126 (1968).

76 Roe, 410 U.S. at 113; Griswold, 381 U.S. at 479.

77 Roe, 410 U.S. at 153 . 
abortion to Genos are inextricably entwined. Consequently, protecting birth control, and particularly abortion, inexorably leads to protecting Genos. If a couple desires a child and the husband is infertile or the wife carries a genetic defect, could the legislature forbid reproduction by artificial insemination or by in vitro fertilization of a donated egg? Surely not. ${ }^{78}$

The childbearing experience, which may be central to a woman's personal identity and to her concept of a meaningful life, should not lightly be impaired. ${ }^{79}$ Roe itself acknowledged that various reproductive techniques are related

by new embryological data that purport to indicate that conception is a "process" over time, rather than an event, and by new medical techniques such as menstrual extraction, the "morning-after" pill, implantation of embryos, artificial insemination, and even artificial wombs. ${ }^{80}$

If one technique of selective reproduction-abortion-is constitutionally protected in the name of reproductive privacy, the same protection from unwarranted state interference likely extends to all such techniques.

Once the above artificial reproductive techniques are permitted for some purposes, government certainly should not be allowed to determine whether a particular purpose is satisfactory or whether a particular individual is undertaking the process for that purpose. ${ }^{81}$ Likely, the standards for doing so would be constitutionally impermissible. For example, could government permit in vitro fertilization to overcome infertility but not to improve intelligence? Alternatively, if infertility is established, could government preclude the infertile couple from using the reproductive material

${ }^{78}$ See Robertson, 59 So. Cal. L. Rev. at 957-67 (cited in note 34) (arguing that procreative liberty affords parents broad discretion in fashioning their children); Note, Frozen Embryos: The Constitution on Ice, 19 Loyola L.A. L. Rev. 267, 276-81 (1985) (arguing that Roe v. Wade protects a procreative right to freeze embryos and to destroy frozen embryos). But see Ozar, The Case Against Thawing Unused Frozen Embryos, 15 Hastings Ctr. Report 7 (Aug. 1985) (arguing that the community's interest in human life and the absence of the frozen embryo from the womb restrict the option of destroying it).

79 John Robertson has aptly observed:

Full procreative freedom would include both the freedom not to reproduce and the freedom to reproduce when, with whom, and by what means one chooses. As reproductive and work patterns change, legal recognition of this aspect of procreative freedom may be necessary to permit some women to fit pregnancy and childbirth successfully into their life plans.

Robertson, $69 \mathrm{Va}$. L. Rev, at 406 (cited in note 50).

so 410 U.S. at 161.

31 See id. at 153-54; Griswold, 381 U.S. at 485. 
of particularly intelligent (or otherwise desirable) individuals?

Moreover, standards for appraising the purposes to be served by reproductive techniques, even if permissible, would be unmanageable. Suppose that a couple were physically capable of having children but did not wish to do so because the child would likely be born with some genetic defect. How severe must that defect be before the couple should have a right to obtain (possibly purchase) and use the reproductive material of someone else? Suppose the couple considers a child below a certain intelligence or size to be genetically defective. Lastly, suppose that two people consider reproduction to be a meaningful experience only if they have a child of a certain kind. Could government deprive that couple of donated sperm, eggs, or wombs in order to thwart the couple's reproductive plan? Moreover, how would government regulate the distribution of, for example, semen? Would it enter the bedroom or test the resultant children? Questions like these may have provoked Justice Blackmun's suggestion in Roe that constitutional safeguards extend to these various reproductive technologies. ${ }^{82}$

AEQUUS: The enterprise of divining traditions upon which to rest constitutional decisions is problematic. It is difficult to characterize Roe itself as a protection of traditional rights. A majority of. the states restricted abortion for more than a century before the decision. ${ }^{83}$ Broad readings extending $R o e$ are even more dubious.

Further, judicially declared "fundamental rights" tend to be malleable. The rights announced in Griswold and Roe have been limited considerably in recent Supreme Court decisions. Maher $v$. $R_{o} e^{84}$ and Harris v. McRae $e^{85}$ conclude that the right to procreative liberty does not include a right to state financial support of abortions. Bowers v. Hardwick ${ }^{88}$ suggests that Roe v. Wade does not create a general zone of personal sexual privacy into which govern-

82 Roe, 410 U.S. at 161.

${ }^{83}$ Id. at 174 (Rehnquist, J., dissenting) (citation omitted).

st 432 U.S. 464 (1977) (upholding denial of state funding for abortions).

8s 448 U.S. 297, 316 (1980) (upholding denial of federal funding for abortions) ("[A]lthough government may not place obstacles in the path of a woman's exercise of her freedom of choice, it need not remove those obstacles not of its own creation.").

88 $106 \mathrm{~S}$. Ct. 2841 (1986) (upholding state sodomy law). The jurisprudence of fundamental rights has proved malleable on other occasions: In Buck v. Bell, 274 U.S. 200 (1927), the Supreme Court upheld compulsory sterilization of imbeciles. More recently, on the other hand, the California Supreme Court invoked the jurisprudence of fundamental rights to invalidate a state statute prohibiting sterilization of mentally disabled persons. Conservatorship of Valerie N., 40 Cal.3d 143, 160-62, 219 Cal. Rptr. 387, 398-400, 707 P.2d 760, 77173 (1985). The court in Valerie $N$. argued that by withholding sterilization from an incompetent woman, the statute deprived her of her only realistic opportunity for contraception and, consequently, restricted her chances for self-fulfillment. 
ment is forbidden to intrude. Such malleability readily allows Congress to ban Genos without relinquishing the doctrine of substantive due process. Congress rightly can conclude that our society comprehends no tradition protecting the right to remodel another human being genetically.

Even if it were law rather than obiter dicta, language in Roe about artificial insemination and other new reproductive techniques would not legitimate Genos. All of these techniques concern the process of conceiving, while Genos concerns the process of fashioning a particular type of child.

2. Is there an Analogy between Genos and the Right to Select the Education of One's Children?

LIBERTAS: Liberty in child rearing and liberty in child bearing both shield the family from governmental intrusion. ${ }^{87}$ The Court has recognized liberty interests protecting the nuclear and extended family structures. ${ }^{88}$ Indeed, it has afforded parents rather broad leeway, concluding that they retain their child rearing prerogatives even if they have not been "model parents."

The right to form the body and mind with Genos is analogous to molding the child through education. The Court has been particularly interested in safeguarding parental control over the child's education. It has protected the parents' right to choose the school that their child will attend ${ }^{90}$ and to influence her education in the public school system.91 It even has enforced the parental right to choose the child's religious upbringing, ${ }^{92}$ an area that may be more personal to the child than Genos itself.

Protecting Genos as part of the educational aspect of child

87 Acknowledging that it "has frequently emphasized the importance of the family," the Court observed in Stanley $v$. Illinois :

The rights to conceive and raise one's children have been deemed "essential," . . "basic civil rights of man," . . and "[r]ights far more precious . . than property rights" .... "It is cardinal with us that the custody, care and nurture of the child reside first in the parents, whose primary function and freedom include preparation for obligations the state can neither supply nor hinder."

405 U.S. 645, 651 (1972), discussed in Robertson, 69 Va. L. Rev. at $414 \mathrm{n} .23$ (cited in note 50).

ss Moore v. City of East Cleveland, 431 U.S. 494 (1977) (holding that liberty interests protected under substantive due process include "extended" as well as nuclear family); Note, 58 N.Y.U. L. Rev. at 176-77 (cited in note 68).

${ }^{80}$ Santosky v. Kramer, 455 U.S. 745, 753 \& n.7 (1982), quoted in Note, 58 N.Y.U. L. Rev. at $176 \mathrm{n} .91$ (cited in note 68). These cases do not, however, delineate the scope of parents' authority over their children. 58 N.Y.U. L. Rev. at 177.

- Pierce v. Society of Sisters, 268 U.S. 510, 534 (1925).

91 Meyer v. Nebraska, 262 U.S. 390, 400 (1923).

22 Wisconsin v. Yoder, 406 U.S. 205, 213-14 (1972). 
rearing may advance other constitutional interests in addition to that of parental liberty. ${ }^{93}$ In building the foundation for speech and expression, education is closely aligned with first amendment interests in self-actualization as espoused by Thomas Emerson. ${ }^{94}$ The very essence of a free society lies in the liberty of each individual citizen to develop in the direction that she pleases. Genos advances the prospects for self-actualization of its recipients: increased strength and intelligence both broaden their range of opportunities and augment their chances of realizing their life plans.

Other first amendment interests, which benefit society more broadly, also justify the protection of Genos. In Emerson's view, freedom of expression nurtures not only self-actualization, but also the pursuit of knowledge and truth and, ultimately, inspires social change. ${ }^{98}$ Genos unequivocally fuels the enterprise of learning. The superior cognitive and communicative ability it produces will enhance the process of societal development by advancing the discovery and articulation of new ideas.

AEQUUS: Genos may well fuel social change and the pursuit of knowledge. The social change that occurs may, however, take us in the wrong direction or produce undesirable results. Likewise, whether Genos advances self-fulfillment depends upon how that concept is defined.

Even if the first amendment is designed to promote self-actualization, ${ }^{96}$ this concept does not so clearly relate to the biological capacity to achieve as it relates to achieving one's natural biological capacity. While the drug may augment the self-fulfillment of Genos people by increasing their chances to attain some ideal of strength and intelligence, ${ }^{97}$ this development travels well beyond the function of the first amendment.

Indeed, Genos actually may undermine first amendment values. Comparing American democracy to a large town meeting, Alexander Meiklejohn claimed that the essential purpose of first amendment jurisprudence is to ensure that all speak, so that the will of the majority can be ascertained. By guaranteeing the voice of each member of society, the first amendment supplies a precon-

9s Shapiro, 48 So. Cal. L. Rev. at 358-62 (cited in note 10).

24 Emerson, Freedom of Expression at 6 (cited in note 2).

${ }^{25}$ Id. at 6-7.

- See generally Burt Neuborne, A Rationale for Protecting and Regulating Commercial Speech, 46 Brooklyn L. Rev. 437, 448 n.28 (1980).

${ }_{97}$ Because the drug may diminish the self-esteem of non-Genos people, it may well impede their self-actualization. See notes $338-42$ and accompanying text below. 
dition of democratic governance. ${ }^{88}$ In Meiklejohn's "town meeting," court-imposed time, place, and manner restrictions ensure that no individual or group will dominate the meeting and thereby drown out the views of others. ${ }^{98}$ Superior cognitive abilities afforded by Genos will facilitate such domination. Insofar as Genos people may better perceive what is best for society, perhaps their ideas should win out. Nonetheless, even Genos people with the best intentions likely will skew public debate in their own interests.

Of course, first amendment jurisprudence already countenances some gross disparities in speaking capacity predicated on wealth. ${ }^{100}$ Still, Genos people may possess both superior wealth and natural ability; only the wealthy will be able to afford the drug, and superior natural ability will simply help the rich to get richer. Consequently, the drug will exacerbate the substantial differences in communicative capability that already threaten free expression.

Moreover, parents' interest in their children's education is not analogous to their interest in Genos. The type of power that Genos exerts over a child's development eclipses the control afforded by education. Parental control over the educational process is limited and diminishes over time. ${ }^{101}$ Genos affects a person in more dramatic and irrevocable ways. One subjected to the procedure will be labeled as a Genos person for life. Even if it did not produce distinguishing physical characteristics, Genos would impose distinguishing behavioral characteristics that might be difficult-and perhaps psychologically trying-to suppress.

\section{B. The Liberty Interests of a Genetically Superior Fetus}

\section{Does a Pre-viable Fetus Have Rights?}

AEQUUS: In determining the magnitude of the asserted liberty interest in Genos, one must balance the countervailing liberty interests of the fetus. A fetus has rights. John Rawls claims that beings who have the "capacity for moral personality" are entitled to equal justice. ${ }^{102}$ Robert Nozick contends that "[t]o be an I, a self, is to have the capacity for reflexive self-reference" ${ }^{\text {"103 }}$ that ap-

\footnotetext{
ss Alexander Meiklejohn, Political Freedom 24-28 (1960).

99 Id.

${ }^{100}$ See notes 6-7 above.

101 Ackerman, Social Justice at 142-50 (cited in note 69).

102 Rawls, A Theory of Justice at 504-10 (cited in note 8).

${ }^{10 s}$ Robert Nozick, Philosophical Explanations 78 (1981).
} 
proximates the capacity for self-knowledge. ${ }^{104} \mathrm{~A}$ fetus has the selfcontained capacity to develop moral personality or self-reference-whereas a sperm cell or an egg does not. ${ }^{105}$ Moreover, shortly after conception a fetus is a separate genetic entity from its mother. ${ }^{108}$

Moral capacity and separate existence demand constitutional protection. While the Supreme Court has rejected the notion that fetuses should be considered human at conception, it has not rejected all claims of fetal rights. Although Roe rhetorically denies all such rights, ${ }^{107}$ the decision postulates a sliding scale that allows the state to recognize powerful fetal rights that, at viability, even trump maternal rights. ${ }^{108}$

It is particularly important that constitutional jurisprudence acknowledge fetal rights in the context of positive genetic engineering. Whatever the possible benefits to the child and society, the degree of control that Genos affords parents-the irreversible manipulation of the child's genetic constitution-makes the cost of error too great to ignore. Moreover, the law does not afford parents absolute control over their children. For example, the Supreme

${ }^{104}$ Id. at 78-82. The concept of reflexive self-reference is quite complex. It parallels linguistic self-reference. Id. at 82 . It also can be explained as a process of synthesizing past actions and precedents to mold the self. Id. at 89-90.

108 Id. at 78-82. See also Roe, 410 U.S. at 161 (conception is a process of gradual fetal development over time).

To determine whether a particular being deserves protection, Jeremy Bentham asked not whether a being could talk or reason but whether it could suffer. Jeremy Bentham, An Introduction to the Principles of Morals and Legislation ch. 17, § 1 , n.1, cited in Robert Nozick, Anarchy, State, and Utopia 337 n.9 (1974). The nervous system of a ten-week-old fetus seems to respond to local stimuli. Horace Robertson, Toward Rational Boundaries of Tort Liability for Injury to the Unborn: Prenatal Injuries, Preconception Injuries and Wrongful Life, 1978 Duke L. J. 1401, 1421. See also Robertson, 59 So. Cal. L. Rev. at 970 (cited in note 34) (biologists disagree about whether the fetus actually feels pain before the twelfth week of pregnancy). A fetus that feels pain merits protection under Bentham's theories. Bentham, Morals and Legislation at ch. 17, § 4, n.1, cited in Nozick, Anarchy, State, and Utopia at 337-38 (cited in this note).

${ }^{108}$ King, 77 Mich. L. Rev. at 1673-74 (cited in note 50). The Roe Court acknowledged this fact. Id. at 1660; Roe, 410 U.S. at 159.

${ }^{307} 410$ U.S. at 158 ("[T] not include the unborn.").

${ }^{108}$ Id. at 163-64. Patricia King uses the capacity criterion to predicate fetal rights on the potential to develop human traits such as rationality. King, 77 Mich. L. Rev. at 1668-69, 1677 (cited in note 50). She places fetal rights on a developmental continuum of rights, maintaining that fetuses cannot make the same claims as children, who, in turn, cannot claim the rights that teenagers or adults can. Id. at 1672-73. This developmental perspective supplies one basis for a fetal claim for protection against Genos. Unlike the aborted fetus-that will cease to exist after the abortion-the Genos fetus will live to see the day when it not only has constitutional protection, but when its genetic engineering will have a real and lasting effect on its life. 
Court has struck down parents' authority over the abortion decisions of their minor children. ${ }^{100}$ This suggests that the familial relationship is not immune from state intrusions. ${ }^{110}$ Such a ruling also recognizes a liberty interest in the child that prohibits physical intrusions like Genos. ${ }^{111}$ One cannot distinguish Genos based on the notion that the fetus cannot consent whereas the minor can. Unemancipated, immature minors-who by definition cannot decide-have a constitutional right to obtain abortions by petitioning a court or an administrative tribunal. ${ }^{112}$

A mother's decision to carry a fetus to term-in other words, her consent to give birth-is another basis for recognizing fetal rights. Several commentators have predicated the rights of a viable fetus on the theory that a woman implicitly relinquishes her own autonomy interests by deciding to carry her child to the point of viability. ${ }^{113}$ This rationale can be carried one step further by asserting the rights of even a pre-viable fetus against the parents on the basis of their decision to carry the fetus to term. ${ }^{114}$ Indeed, several commentators have advocated that a child be permitted a right of action against a mother who was at fault in causing it harm in utero. ${ }^{115}$

The courts have recognized a duty to protect the fetus from prenatal injuries, allowing recovery by the child if she is born alive. ${ }^{116}$ Furthermore, most courts that have faced the issue have

109 See note 61 above.

110 In his dissent in H.L. v. Matheson, Justice Marshall suggested that state intrusions into this decision of the child alter the normal pattern of interaction within the family. 450 U.S. at 438 n.24 (Marshall, J., dissenting). One might retort that court approval of an abortion for an unemancipated, immature minor intrudes on a family's self-developed pattern of parent-child decision making. See Bellotti v. Baird, 443 U.S. 622, 657 (1979) (White, J., dissenting).

${ }^{111}$ See Planned Parenthood of Missouri v. Danforth, 428 U.S. 52, 74 (1976) ("Minors, as well as adults, are protected by the Constitution and possess constitutional rights.").

112 Bellotti, 443 U.S. at 647.

11 See Ackerman, Social Justice at 128-29 (cited in note 69); Regan, 77 Mich. L. Rev. at 1643 (cited in note 69).

${ }^{134}$ See Robertson, 69 Va. L. Rev. at 442, 446-47 (cited in note 50).

116 See, e.g., id. at 447 n.129 (mother should be liable for engaging in activities that are toxic to the fetus during pregnancy and failing to undergo therapy necessary for a healthy birth); Note, Parental Liability for Prenatal Injury, 14 Colum. J. L. \& Soc. Probs. 47 (1978) (advocating liability for parental negligence); Note, Recovery for Prenatal Injuries: The Right of a Child Against its Mother, 10 Suffolk U. L. Rev. 582, 607 (1976) (advocating gross negligence standard). See also Grodin v. Grodin, 102 Mich. App. 396, 301 N.W.2d 869 (1980) (child allowed action against mother for damages to child's teeth caused by mother's use of medication during pregnancy). But see Note, 95 Yale L. J. at 614-25 (cited in note 70) (arguing that recognition of such fetal claims violates maternal liberty).

${ }^{116}$ See W. Page Keeton, Dan Dobbs, Robert Keeton, and David Owen, Prosser and Keeton on the Law of Torts 367 (5th ed. 1984) ("Prosser \& Keeton"), and cases cited 
allowed recovery when the fetus is born alive even though the injury was inflicted before it was viable or "quick."117 Prosser and Keeton on the Law of Torts states:

Viability of course does not affect the question of legal existence of the unborn, and therefore of the defendant's duty, and it is a most unsatisfactory criterion, since it is a relative matter, depending on the health of the mother and child and many other matters in addition to the stage of development. ${ }^{118}$

Similarly, the Restatement (Second) of Torts advocates recovery for injury occurring at any time after conception, providing that tortious conduct and causation can be established. ${ }^{119}$ The criminal law and the law of inheritance also recognize the rights of a previable fetus. ${ }^{120}$

Controlling Genos is the only way to protect fetal liberty interests. The drug enables parents permanently to shackle their children to a particular life. Any possibility of living as a non-Genos person is lost: daily existence may be punctuated by jealousy, ridicule, and exclusion. Essential human dignity may also be compromised by the realization that one is the product of genetic fabrication. ${ }^{121}$ These interests can only be protected if the fetus

therein.

${ }^{117}$ Id. at 368-69. A majority of jurisdictions have allowed recovery under their wrongful death statutes when the fetus was not even born alive. Id. at 369-70.

$118 \mathrm{Id}$. at 369 . The authors defend recovery for injury to a pre-viable fetus born alive by emphasizing that viability is a relative matter contingent on many circumstances and that the child remains injured regardless of when the injury occurred. Id. See also Robertson, 1978 Duke L. J. at 1428,1438 (cited in note 105).

However, most federal courts have rejected fetal damage claims brought under 42 U.S.C. $\$ 1983$, which creates a cause of action in damages for any person deprived of constitutional rights under color of state law. These courts have concluded that the fetus is not a "person" within the meaning of the statute. See Guyton v. Phillips, 606 F.2d 248, 250 (9th Cir. 1979) (dicta); Harman v. Daniels, 525 F. Supp. 798, 800 (W.D. Va. 1981); Poole v. Endsley, 371 F. Supp. 1379, 1382 (N.D. Fla. 1974). This view is not universally shared: despite several contrary federal decisions, a federal district court in Connecticut followed the trend of state authority, declaring a five and one-half month old, viable fetus a person under section 1983. Douglas v. Town of Hartford, Connecticut, 542 F. Supp. 1267, 1270 (D. Conn. 1982).

119 Restatement (Second) of Torts $\$ 869$ (1977).

120 Guido Calabresi, Ideas, Beliefs, Attitudes, and the Law 94 (1985); Note, 95 Yale L. J. at 601-03 (cited in note 70). Indeed, Calabresi has argued that Roe $v$. Wade ignored the longstanding "gravitational pull--which said that for some purposes a fetus was surely protected by our law." Id. at 95 .

${ }^{121}$ In reference to cloning, Laurence Tribe has remarked:

Yet one's sense of "selfhood" or "personhood," and the related experience of one's autonomous individuality, may depend, at least in some cultural settings, on the ability to 
has rights that are powerful enough to trump those of its parents. LIBERTAS: Children have certain narrow liberty interests. However, these interests are not implicated by Genos for several reasons. First, while minor children have some rights, the rights of ten-week-old fetuses are much more limited. Second, while a court may be able to make an individualized determination about the benefits of an abortion to a particular fetus, it is much harder to assess the benefits of Genos for a given child. Third, limits on maternal abortion decisions, like limits on the ability of parents to interfere in their child's abortion decision, grow out of skepticism that the parent will adequately consider her child's interests when they diverge from her own. ${ }^{122}$ Genos does not produce such a conflict of interest between parents and child.

These points require further discussion. Under Roe, a fetus has no cognizable liberty interests at the time a decision to use Genos would be made. In Roe, the Supreme Court declared that "the word 'person,' as used in the Fourteenth Amendment, does not include the unborn." ${ }^{123}$ As a result, the state cannot interfere during the first trimester of pregnancy with the decision by the mother and her attending physician to abort. ${ }^{124}$ If the woman can choose no life at all for the fetus, it follows a fortiori that she can choose a superior life for it-a result that certainly seems more desirable from the standpoint of the fetus.

Even if the fetus possesses some liberty interests, it certainly has none that overcome the parent's right to use Genos. ${ }^{125}$ Fetal rights against parents are very limited in scope. It is clear that parents may not abuse their fetus in utero with the specific intent of causing imbecility or physical deformity, but the legitimacy of neg-

think of oneself as neither fabricated genetically nor programmed neurologically. . . . Laurence H. Tribe, Technology Assessment and the Limits of the Fourth Discontinuity: The Limits of Instrumental Rationality, 46 So. Cal. L. Rev. 617, 648 (1973). See also President's Commission at 68 (cited in note 10).

${ }^{122}$ Joseph Goldstein, Medical Care for the Child at Risk: On State Supervision of Parental Autonomy, 86 Yale L. J. 645, 662 (1977).

138410 U.S. at 158. For various perspectives on fetal rights in the context of abortion, see generally Margery Shaw and A. Edward Doudera, eds., Defining Human Life: Medical, Legal, and Ethical Implications (1983).

124 Roe, 410 U.S. at 163 . After the first trimester, the state can regulate to promote the mother's health. After viability, the state's interest in the potential life of the fetus becomes sufficiently compelling to empower it to proscribe abortion "except where it is necessary, in appropriate medical judgment, for the preservation of the life or health of the mother." Id. at 164-65.

${ }^{125}$ An interesting question is what happens when parents disagree about the decision of whether a conceived embryo should become a Genos child. Consider Danforth, 428 U.S. at 71 (state may not require married woman to obtain husband's consent to abortion). 
ligence actions for in utero harm is far less certain. ${ }^{128}$ The controversy over parental tort liability brings into focus a deeper issue: if a pre-viable fetus brought to term has some right not to be harmed by its parents, what counts as harm? If parents would not have had a particular child at all without Genos, that child would seem to have no complaint.

Most importantly, in contrast to in utero mutilation, few people would consider Genos an unambiguous detriment. If they did, no need to ban or regulate it would exist. Reasonable people will differ on the advantages of Genos's use. The question then becomes: "Who decides?"

2. Should the Parents or the Government Determine Genetic Liberty Interests on Behalf of a Pre-Viable Fetus?

LIBERTAS: The worst answer to this question is a blanket ruling that no genetic engineering is allowed. The best solution is to allow the use of all available technologies and eliminate the intrusion of government into a couple's personal decisions about procreation-decisions that the government is unlikely to improve. The courts have already recognized this and have given parents broad discretion to decide what is harmful and what is beneficial to their children.

"Wrongful life" suits provide some guidance on this point. In these suits, a child seeks recovery against a physician for a genetic deformity on the theory that the physician's failure to inform its parents of the deformity in time to abort caused it to endure a life of suffering. ${ }^{127}$ Many jurisdictions that have faced such claims have denied them. ${ }^{128}$ Most courts have justified this result by emphasizing the impossibility of identifying the harm in such a situation: "The infant plaintiff would have us measure the difference between his life with defects against the utter void of non-existence, but it is impossible to make such a determination."129 Relying on this same rationale, courts that have allowed "wrongful life" suits

126 See note 115 above.

127 Prosser \& Keeton at 370 (cited in note 116).

${ }^{128}$ Id. at 371 (citing cases); Thomas Rogers, Wrongful Life and Wrongful Birth: Medical Malpractice in Genetic Counseling and Prenatal Testing, 33 S.C. L. Rev. 713, 713-14 (1982).

${ }^{129}$ Gleitman v. Cosgrove, 49 N.J. 22, 25, 227 A.2d 689, 692 (1967), discussed in Prosser \& Keeton at 371 (cited in note 116). New Jersey now allows special damages in wrongful life actions. Procanik by Procanik v. Cillo, 97 N.J. 339, 478 A.2d 755 (1984). See also Payton v. Abbott Labs, 386 Mass. 540, 437 N.E.2d 171 (1982), a DES decision based on "wrongful life" case rationales. Because DES helped to prevent miscarriages, the court permitted defendants to establish that plaintiffs would not have been born absent their mothers' use of the drug. 
have limited recovery to special damages such as medical expenses. ${ }^{130}$ If a child with clear genetic disadvantages lacks a claim not to have been born, surely the advantaged Genos child lacks a claim that he would rather never have been born than to have been genetically engineered.

Recovery under wrongful life theory benefits the child; the correlative parental cause of action is "wrongful birth." In a wrongful birth action, parents seek to recover for the impairment of their abortion decision caused by failure to be informed of their fetus's genetic defects. ${ }^{131}$ In sharp contrast to the hostile treatment of children's wrongful life claims, courts have overwhelmingly approved parents' wrongful birth claims. ${ }^{132}$ Widespread rejection of wrongful life actions illustrates the reluctance of judges to empower themselves-or perhaps any other governmental branch-to override parental decisions in order to protect fetal interests. ${ }^{133}$ Likewise, the courts' nearly unanimous recognition of an action for wrongful birth reveals their preference for leaving such genetic engineering issues to parents.

Moreover, the decision-making rights of parents already extend to a variety of eugenics. The predicate for wrongful birth cases is the inviolable right of abortion prior to viability. ${ }^{134}$ The abortion prerogative underwrites a type of positive as well as negative genetic engineering. Today, for example, amniocentesis allows parents to select their child's sex and to screen for a variety of

${ }^{130}$ See Turpin v. Sortini, 31 Cal.3d 220, 643 P.2d 954, 182 Cal. Rptr. 337 (1982); Siemieniec v. Lutheran General Hospital, 134 Ill. App. 3d 823, 480 N.E.2d 1227 (1985); Procanik, 97 N.J. at 339, 478 A.2d at 755; Harbeson v. Parke-Davis, Inc., 98 Wash.2d 460, 656 P.2d 483 (1983) (en banc); Azzolino v. Dingfelder, 322 S.E.2d 567 (N.C. App. 1984).

151 See Prosser \& Keeton at 370-71 (cited in note 116).

${ }^{192}$ See id. (citing cases); Rogers, 33 S.C. L. Rev. at 713-14 (cited in note 128).

13s California's experience in this connection is instructive. Curlender v. Bio-science Laboratories, 106 Cal. App. 3d 811, 165 Cal. Rptr. 477 (1980), upheld a complaint by a child against its parents for not aborting it. The California legislature reversed this result. Cal. Civ. Code $\S 43.6$ (West 1982). Later in 1982, the California Supreme Court specifically held that-even in the context of a child's wrongful life action-the parents rather than the courts are delegated the authority to make the abortion decision on behalf of their deformed child. Turpin v. Sortini, 31 Cal.3d 220, 643 P.2d 954, 182 Cal. Rptr. 337 (1982).

${ }^{134}$ See Roe, 410 U.S. at 162-64. Because the parents can abort for any reason prior to viability, they can clearly abort for eugenic reasons. As a result, wrongful birth cases thrust upon doctors the responsibility of making parents informed decision makers in their role as genetic engineers. This parental role is grounded in two separate claims. The first is the parents' right to exercise control over the reproductive process in their own interests; the second is their right to represent the interests of the fetus in this vital decision. Alexander Capron, Informed Decisionmaking in Genetic Counseling: A Dissent to the "Wrongful Life" Debate, 48 Ind. L. J. 581, 602 (1973); Alexander Capron, Tort Liability in Genetic Counseling, 79 Colum. L. Rev. 618, 648, 653 (1979). 
genetic defects. ${ }^{135}$ The right to abortion bestowed in Roe in practice allows people to engage in a form of genetic engineering. A fortiori, it must confer the right to engage in genetic engineering without using abortion. If the prospect of genetic manipulation through abortion is permitted under the trimester system in Roe, then surely genetic manipulation that takes place by improving rather than destroying the fetus must be permissible. To conclude otherwise would be to encourage the admittedly crude and draconian process of genetic engineering through abortion. ${ }^{136}$

Granting parental control over positive and negative genetic engineering also accords with the broad discretion generally afforded parents to decide medical matters for their children. While courts sometimes have been willing to override this discretion when the child's life is in imminent danger, parental choice is quite broad when life is not immediately threatened-even when there is grave risk of eventual death. ${ }^{137}$ Exemplifying this position is In re

135 Harold Green, Genetic Technology: Law and Policy for the Brave New World, 48 Ind. L. J. 559, 560 (1973). In vitro fertilization and other new techniques should further expand parents' capability for genetic engineering. See John Fletcher, Moral Problems and Ethical Issues in Prospective Human Gene Therapy, 69 Va. L. Rev. 515, 530-31 (1983); Robertson, $69 \mathrm{Va}$. L. Rev. at 423 (cited in note 50 ). The wrongful life action clearly increases the incentives for negative genetic engineering: the prospect of facing the jury puts doctors under pressure to diagnose and inform parents of fetal imperfections-and to encourage them to abort in some circumstances. See Note, Father and Mother Know Best: Defining the Liability of Physicians for Inadequate Genetic Counseling, 87 Yale L. J. 1488, 1505 (1978) (wide range of duties should be imposed on doctors to keep abreast of genetic diagnostic techniques and to inform parents of genetic risks).

${ }^{138}$ There are also significant practical problems with relying heavily on abortion as a means of genetic engineering. Such reliance could significantly increase the number of abortions.

${ }^{137}$ See Note, The Outer Limits of Parental Autonomy: Withholding Medical Treatment From Children, 42 Ohio St. L. J. 813, 818 (1981) ("In situations that are not imminently life-threatening, courts generally give parents great discretion and uphold their decisions as long as they are in the child's best interests and not arbitrary."); Goldstein, 86 Yale L. J. at 651 (cited in note 122) (courts should respect parental discretion even in life-threatening medical decisions unless parents refuse to treat a child who can expect "a life of relatively normal, healthy growth toward adulthood").

Judge Gesell has suggested in dicta that "to the extent the [federal] regulation is read to eliminate the role of the infant's parents in choosing an appropriate course of medical treatment, its application may in some cases infringe upon the interests outlined in cases such as . . . Roe v. Wade. . . and Griswold v. Connecticut." American Academy of Pediatrics v. Heckler, 561 F.Supp. 395, 403 (D.D.C. 1983). American Academy of Pediatrics invalidated federal regulations that prohibited discrimination in the medical treatment of handicapped fetuses on grounds that the Department of Health and Human Services failed to comply with the Administrative Procedure Act. In a related case, Judge Wexler echoed Judge Gesell by suggesting that for "the federal government to involve itself in the choice among alternative reasonable medical treatments for handicapped children . . . would raise grave constitutional questions concerning the rights to privacy." United States v. Univ. Hosp. of State Univ. of New York, 575 F. Supp. 607, 616 (1983), aff'd, 729 F.2d 144 (2d Cir. 
Quinlan, ${ }^{138}$ which allowed the parents to represent their comatose teenage child in deciding to cut off life support systems. Also illustrative are the Infant Doe cases, which allowed parents to discontinue providing the necessities of life to their physically impaired newborns. ${ }^{139}$ These cases demonstrate that parents can make important medical decisions for their offspring beyond viability. If parents are empowered to decide questions of life and death for their children, they should certainly be allowed to decide whether to use Genos.

AEQUUS: The courts have frequently allowed governmental assessments of the child's interests to supersede calculations made by the parents. The state also can assert its own interests in parental decisions, interests that may trump those of the parents and the child. Notable examples include child labor laws, child abuse and neglect laws, and post-viability abortion restrictions. Some state laws currently address genetic engineering itself.

In a clear example of overriding parental liberty, the Supreme Court upheld the application of child labor laws against a Jehovah's Witness. The state's interest overrode the guardian's free exercise claim that selling religious literature was part of the child's religious duty. ${ }^{140}$ Similarly, every jurisdiction in the United States has laws proscribing child abuse and neglect. ${ }^{141}$ Many commentators have noted the breadth and vagueness of these statutes:142

1984).

Recently, the Supreme Court set aside a newly promulgated version of these regulations as unsupported by statutory authority. In a footnote, the Court intimated that broad parental discretion over the treatment of their child may be a matter of constitutional right. See Bowen v. American Hosp. Ass'n, 106 S. Ct. 2101, 2113 n.13 (1986) (plurality opinion).

1ss 70 N.J. 10, 38-42, 355 A.2d 647, 662-64 (1976).

${ }_{139}$ Rather than predicate the parents' power on their status as representatives of the child, the Infant Doe Court focused on the parents' rights outweighing those of the child when the child lacked an opportunity for a minimally adequate life. Note, Withholding Treatment from Defective Infants: "Infant Doe" Postmortem, 59 Notre Dame L. Rev. 224, 235 (1983).

140 Prince v. Massachusetts, 321 U.S. 158 (1944). The Court remarked:

Parents may be free to become martyrs themselves. But it does not follow they are free, in identical circumstances, to make martyrs of their children before they have reached the age of full and legal discretion when they can make that choice for themselves.

Id. at 170. See also Jacobson v. Massachusetts, 197 U.S. 11 (1905) (upholding compulsory vaccination law against parental liberty claim).

${ }^{141}$ Robert H. Mnookin, Child-Custody Adjudication: Judicial Functions in the Face of Indeterminacy, 39 L. \& Contemp. Probs. 226, 240-41 (Summer 1975); Note, The Child's Rights to "Life, Liberty and the Pursuit of Happiness": Suits by Children Against Parents for Abuse, Neglect and Abandonment, 34 Rutgers L. Rev. 154, 178-79 (1981).

112 See, e.g., Mnookin, 39 L. \& Contemp. Probs. at 240-42 (cited in note 141); Sheila Reynolds and Roy Lacoursiere, Interminable Child Neglect/Custody Cases: Are there Better 
"typical language is the definition of a neglected child as one who 'lacks proper parental care because of the faults or habits of his parents." "143 This standard permits the state to intervene in the parent-child relationship for myriad reasons, many of which are quite appropriate. Among these are physical abuse, sexual abuse, absence of a "moral" environment, and failure to provide food, clothing, shelter, medical care, education, or supervision. ${ }^{144}$ These various grounds generate an estimated one million reported cases of child abuse and neglect annually that produce an estimated 150,000 to 200,000 court actions. ${ }^{145}$ The scope of accepted state intrusion into the familial relationship is likewise large: a substantial percentage of the cases conclude by separating the child from the home. ${ }^{146}$

Thus, the general principle is that the courts are empowered to intervene in family decisions if the government can persuade them that such intervention would serve "the best interests of the child." ${ }^{147}$ Significantly, many states have extended this protection against child abuse to fetuses. Sanctions include withdrawal of parental custody of the newborn child, criminal penalties, and injunctions forcing medical treatment during pregnancy. ${ }^{148}$ Strikingly, the state's conception of a child's well-being may overcome parental choice even in the core area of procreative freedom itself. The Roe decision specifically allows the state's interests in the potential life of the fetus to supersede the mother's autonomy over her own

Alternatives?, 21 Fam. L. Quart. 239, 258-73 (1982-83).

${ }^{143}$ Reynolds and Lacoursiere, 21 Fam. L. Quart. at 264 (cited in note 142), quoting Ohio Rev. Code Ann. § 2151.03(B) (Baldwin 1978).

144 Reynolds and Lacoursiere, 21 Fam L. Quart. at 264-65 (cited in note 142); Mnookin, 39 L. \& Contemp. Probs. at 240-41 \& n.68 (cited in note 141). See Laurence Houlgate, The Child \& the State 130 (1980) ("[C]ourts have been known to grant neglect petitions on the ground that parents have failed to provide their child with the proper moral environment, proper care, safe home conditions, and satisfaction of emotional needs.").

${ }_{145}$ Note, Lawyering for the Abused Child: "You Can't Go Home Again," 29 U.C.L.A. L. Rev. 1216, 1217 \& n.10 (1982).

148 Reynolds and Lacoursiere, 21 Fam. L. Quart. at 265 (cited in note 142).

${ }^{147}$ Joseph Goldstein, Anna Freud, and Albert Solnit, Beyond the Best Interests of the Child 3-7, 53-64 (1973); Note, 29 U.C.L.A. L. Rev. at 1220-27 (cited in note 145). Not only are the courts and legislatures involved, but administrative agencies permeate the process. Mnookin, 39 L. \& Contemp. Probs. at 241-42 (cited in note 141); Reynolds and Lacoursiere, 21 Fam. L. Quart. at 267-68 (cited in note 142).

${ }^{248}$ Note, 95 Yale L. J. at 604-05 (cited in note 70). Consider also the decision in Parham v. J.R., 442 U.S. 584 (1979), in which the Supreme Court upheld the state's right to infringe on parental authority when the physical or mental health of the child is in jeopardy. 442 U.S. at 603 . Genos affects one's whole genetic makeup-an interest at least as fundamental as health, and one which affects health. 
body after viability. ${ }^{148}$

Although the courts have, by permitting abortion, indirectly recognized a parental right to engage in negative genetic engineering, this does not suggest that parents have exclusive or absolute rights to do so. The government is also involved in the enterprise of negative genetic engineering. Examples include prohibiting incest and requiring that couples be tested for disease and other problems prior to marriage. ${ }^{100}$ Here, too, state assessments of the rights of the unborn have prevailed over competing appraisals made by parents.

The state not only represents the child, but it also may assert its own interests in order to trump individual liberty claims, regardless of whether those claims are asserted by parents or by the affected children themselves. With regard to genetic engineering, the Supreme Court in the past has approved compulsory sterilization for imbecility. ${ }^{151}$ While particular applications of this power are open to question, the existence of some state prerogative appears to continue. ${ }^{152}$

In areas other than genetic engineering, the Court has supported compulsory education laws in the face of parental opposition. ${ }^{153}$ It also has sustained laws against polygamy despite their infringement on certain conceptions of the family founded on religious beliefs. ${ }^{154}$ Similarly, in Jacobson $v$. Massachusetts, ${ }^{155}$ the Court endorsed compulsory child vaccination statutes over the pro-

149 Roe, 410 U.S. at 154.

${ }^{150}$ Note, Asexual Reproduction and Genetic Engineering: A Constitutional Assessment of the Technology of Cloning, 47 So. Cal. L. Rev. 476, 534-35 (1974).

181 Buck, 274 U.S. at 207-08.

162 The Roe court cited Buck v. Bell for the proposition that the Court has in the past refused to recognize an unlimited right over control of one's body. 410 U.S. at 154. Compare John Nowak, Ronald Rotunda, and J. Nelson Young, Constitutional Law 737 (1983), expressing doubt that the Supreme Court would follow Buck and uphold compulsory sterilization of imbeciles today. The other Supreme Court case dealing with sterilization, Skinner, 316 U.S. at 535, rested on equal protection grounds. Id. at 538. In Skinner, the Court struck down a law that authorized the sterilization of convicts who had committed more than two offenses involving moral turpitude. The Court concluded that because sterilization was so intrusive, the judiciary should carefully monitor it to ensure that it was not administered invidiously or arbitrarily. Id. at 541.

15s Andrew Kleinfield, The Balance of Power Among Infants, Their Parents and the State, 4 Fam. L. Quart. 409, 414 (1970). As the Court indicated in Plyler v. Doe, 457 U.S. 202 (1982), compulsory education advances both the interests of individual children by equipping them to compete and the interests of a democratic society by supplying tools to govern. Id. at 221 .

1B4 Cleveland v. United States, 329 U.S. 14 (1946); Reynolds v. United States, 98 U.S.

1ss 197 U.S. 11 (1905). See also Zucht v. King, 260 U.S. 174 (1922). 
test of parents and children alike. Recognizing that notions of liberty must be constrained by considerations of order, the Court opined:

If [foregoing compulsory vaccination] be the privilege of a minority then a like privilege would belong to each individual of the community, and the spectacle would be presented of the welfare and safety of an entire population being subordinated to the notions of a single individual who chooses to remain a part of that population. We are unwilling to hold it to be an element in the liberty secured by the Constitution of the United States that one person, or a minority of persons, residing in any community and enjoying the benefits of its local government, should have the power thus to dominate the majority when supported in their action by the authority of the State. ${ }^{156}$

Accordingly, Congress could reasonably conclude that any liberty-based reproductive interests parents may possess in the use of Genos are outweighed by the risks to the child's interest in human dignity and by broader social concerns. The use of Genos raises such broad public questions that society cannot afford to allow individual parents and children to assert a liberty interest that would supplant society's power to decide. Indeed, justifying Genos's availability as an expansion of either fetal or parental liberty is in some ways incongruous: even for those families with the resources to afford the drug, protecting its use may shackle rather than liberate. The "freedom to choose" may be a Hobson's choice: parents who would rather not use the drug must either saddle their children with what they as parents consider an unsavory existence or leave them with a gross competitive disadvantage.

LIBERTAS: Liberty exacts costs. One such cost is the thrusting of difficult decisions onto individuals; but the alternative is relinquishing the individual decision-making prerogative to the government. Another cost of liberty is a degree of economic inequality. But again, the alternatives may be unpalatable: a far lower average level of well-being ${ }^{167}$ and the possibility of far greater eco-

156197 U.S. at 37-38. Concerning the scope of parental discretion in individual medical treatment decisions, Professor Goldstein generally supports broad parental discretion but also recognizes the "generally applicable societal judgments that no parents shall have a choice" in decisions like compulsory vaccination. Goldstein, 86 Yale L. J. at 648 (cited in note 122). See also Green, 48 Ind. L. J. at 568 n.27 (cited in note 135) (discussing broad scope of states' public health powers).

${ }^{137}$ See Friedrich A. Hayek, The Constitution of Liberty 42-44 (1960). 
nomic, social, and political stratification imposed by the government. ${ }^{158}$ Thus, while the state may be justified in some instances either in asserting its judgment of the child's best interest over that of the parents or in asserting its own interests in parental decisions, there must be definite limits on its ability to do so.

Laws by which the state oversees maternal behavior during pregnancy clearly violate procreational autonomy. These laws are rooted in the absolute dependence of the fetus on maternal conduct, and constitute a rapidly expanding and potentially openended burden on the parents. ${ }^{160}$ More importantly, the assertion of liberty interests on the part of the fetus is premised on a false conflict between the liberty interests of parent and fetus. It is the exception rather than the rule that parents act against the best interests of their children. It also is counterintuitive to assume that Genos children, if given the choice, would reject the superiority that the drug engenders. Banning Genos is not analogous to eradicating the evils of epidemics by vaccination or those of illiteracy by education. The fundamentally personal decision to endow one's child with superior traits rests with the parents, not with the state. $^{180}$

\section{The Egalitanian Interests of a Genetically Superior Minority}

Versus the Egalitarian Interests of a Genetically Inferior Majority: Who Would Harm Whom?

1. Could a Genetically Inferior Majority Assert an Interest in Equality of Opportunity or Equality of Condition?

AEQUUS: The constitutional prohibitions against slavery, titles of nobility, and denials of equal protection based on race provide a clear basis for limiting the use of Genos. These prohibitions set bounds on the amount of inequality that will be tolerated for the sake of liberty. To say that one can do as one pleases so long as one does no harm to another merely begs the question: What counts as "harm"? Libertarianism supplies no means of ensuring that individuals possess the resources necessary for self-actualization-or even survival. Similarly, it provides no basis for redressing

183 Id. at 103-17, 170-75.

158 Note, 95 Yale L. J. at 605-20 (cited in note 70).

100 The guidance available from the Supreme Court suggests that it may not impede important scientific developments in genetics. In Diamond v. Chakrabarty, 447 U.S. 303 (1980), the Court allowed genetically engineered bacteria to be patented. The Court rejected policy arguments about "depreciating the value of life," liberally construing the statute to allow the commercial protection of these products. Id. at 316 . 
the inequalities of talent, wealth, and other sources of power occasioned by a phenomenon like Genos-inequalities that easily could be characterized as "harm." Therefore, even if the use of Genos does abridge a parental right superior to competing fetal claims, a compelling state interest still exists to justify prohibiting the drug: the assault on egalitarian values that Genos would effect implicates compelling state interests of constitutional stature. ${ }^{161}$

Even apart from the maniacal racial purity advocated by the Nazis, elitist notions have plagued the history of genetic engineering. Eugenicists have attributed to heredity such qualities as intelligence, industry, and even righteousness. ${ }^{182}$ Earlier in this century, they directly linked many of these faculties to race, ethnicity, physical handicap, and social class. ${ }^{163}$ Inspired by these views, eugenic reformers preached a distinctive gospel of social reform. Fearing that the lower classes were reproducing in greater proportions than the rest of the population, they urged the well-bred to augment their reproductive activities. ${ }^{164}$ They also reformulated notions of charity in Darwinian terms: rather than help people to survive who otherwise would not, charity must help society to better itself. ${ }^{165}$ Finally, the eugenic reformers criticized democracy as a form of government that enabled the ignorant masses to triumph over more deserving experts. ${ }^{166}$

Genos will exacerbate the distance between social classes dramatically and irrevocably. ${ }^{16 z}$ This stratification offends principles of equality of opportunity and equality of condition, central to American ideals. Two critical interests in the area of equality of

181 In the past, the Court has permitted state interests to trump individual liberty interests in procreation. See Planned Parenthood Association v. Ashcroft, 462 U.S. 476 (1983) (upholding requirements that a second physician be present in a post-viability abortion and that a pathology report be filed for all abortions); Roe, 410 U.S. at 150 (holding that abortion procedures subsequent to fetal viability may be regulated "except when it is necessary to preserve the life or health of the mother").

${ }^{162}$ Sir Francis Galton, who coined the term "eugenics," believed that its aim was to give to the "more suitable races or strains of blood" a better chance of prevailing speedily over the "less suitable" than they otherwise would have had. Golding, 15 U.C.L.A. L. Rev. at 464 (cited in note 65).

${ }^{163}$ Robert Cynkar, Buck v. Bell: "Felt Necessities" v. Fundamental Values?, 81 Colum. L. Rev. 1418, 1422-27 (1981).

${ }^{164}$ Id. at 1428. See also Note, 94 Harv. L. Rev. at 1862 (cited in note 10).

${ }^{185}$ Cynkar, 81 Colum. L. Rev. at 1426 (cited in note 163).

188 Id. at 1427. English eugenicists reflected the deeply embedded royalist and aristocratic traditions of eugenic theory. Id. at 1422; Golding, 15 U.C.L.A. L. Rev. at 465-66 (cited in note 65 ). During the 1960 s they proposed that the prohibition of polygamy be abrogated for members of the House of Lords. Gorney, 15 U.C.L.A. L. Rev. at 295 (cited in note 37). They also proposed that sperm banks be created with the semen of knights. Id.

${ }^{167}$ See Shapiro, 48 So. Cal. L. Rev. at 325 (cited in note 10). 
opportunity are education and employment, ${ }^{168}$ both of which enjoy powerful constitutional and statutory protection. ${ }^{169}$ In construing the equal protection clause, the Supreme Court has acknowledged the critical link between equality of educational opportunity and equality of employment opportunity. ${ }^{170}$ Educational opportunity is a function of wealth, effort, and intelligence. Because Genos people will disproportionately possess these resources, the drug will redistribute educational possibilities. This redistribution will be particularly problematic, since intelligence and effort will (potentially) be tied permanently to wealth. ${ }^{171}$

Beyond formal education, the power to attract scarce resources by virtue of being labeled a Genos person will most likely continue throughout life. ${ }^{172}$ Genos people clearly will garner increased influence, ${ }^{173}$ achievement, and wealth. ${ }^{174}$ In some instances,

18 Extensive litigation vindicating rights to education and employment indicates the importance of these areas. See, e.g., Nowak, Rotunda, and Young, Constitutional Law at 639-59, 846-49 (cited in note 152); Barbara Schlei and Paul Grossman, Employment Discrimination Law (1979). Equal opportunity in political power is another value that has been extensively protected against discrimination. See, e.g., Rogers v. Lodge, 458 U.S. 613 (1982) (nullifying racially discriminatory, at-large election districting); Reynolds v. Sims, 377 U.S. 533 (1964) (disallowing weighting of votes according to residency and imposing "one person, one vote" standard for state legislative apportionment); Gomillion v. Lightfoot, 364 U.S. 339 (1960) (invalidating racially discriminatory gerrymandering of election district).

${ }^{169}$ See, e.g., Brown v. Board of Education, 347 U.S. 483 (1954) (per curiam) (discrimination in education); Washington v. Davis, 426 U.S. 229 (1976) (discrimination in employment). See also Title IX of the Education Amendments of 1972, 20 U.S.C. $\$ 1681$ (a) (1982 \& Supp. 1985) (enforcing right of equal access to public education); Title VII of the Civil Rights Act of 1964, 42 U.S.C. $\S 2000 \mathrm{e}-2$ (a) (1982 \& Supp. 1985) (enforcing right of equal access to employment).

${ }^{170}$ Runyon v. McCrary, 427 U.S. 160, 179 n.16 (1976).

171 Disparities in wealth and natural intelligence coupled with the constitutional right to educational choice already result in considerable differences in educational opportunity. See Pierce, 268 U.S. at 510. Even if these differences do not rise to the level of a constitutional violation, the intervention of Genos will grossly aggravate the inequality they produce. Genos will concentrate inequalities by capriciously tying intelligence and effort to wealth. See text at notes $198-200$ below.

172 For discussions of the correlation between intelligence and success, including economic success, see authorities cited in note 10 above. The economic disadvantages that the superiority of Genos people will visit on non-Genos people may be aggravated by the perception that Genos people will generally be superior candidates for employment and other important positions. Rather than make fair individual determinations, employers and athers may find it cheaper to make statistical assumptions that Genos people will prove superior candidates. See generally Posner, The Economics of Justice at 362-63 (cited in note 4). Whether Title VII would proscribe such discrimination depends on whether Genos people are treated as a race within the statute's meaning. See note 203 below (suggesting that discrimination against Genos people may violate Title VII).

${ }^{173}$ See text following note 203 below.

174 Because the drug also engenders superior stamina, it will cancel out the effects of extra effort by non-Genos people. But see Rawls, A Theory of Justice at 312 (cited in note 
disparities in education and employment may be countered with affirmative action, ${ }^{175}$ however, the prospect of using this controversial remedy to deal with yet another form of inequality is not attractive. Considering the disagreement that affirmative action has spawned on the Supreme Court, ${ }^{176}$ one wonders how this strategy can be applied to help non-Genos people, who are the overwhelming majority rather than a minority. ${ }^{172}$

In addition, Genos will offend constitutional provisions that protect another fundamental value: equality of condition. The drug will enthrone a virtually permanent elite. While this effect may not directly abridge the Constitution as now understood, it clearly will undercut notions of equality of condition enshrined in the prohibitions against titles of nobility. ${ }^{178}$ The Constitution does not envision the type of aristocracy that Genos people will constitute. ${ }^{179}$

As the nobility clauses erect an upper limit (albeit lenient) on inequality of condition, the thirteenth amendment enforces a lower limit by proscribing slavery and involuntary servitude. ${ }^{180}$ The thirteenth amendment extends to purely private actions such as the manufacture and use of Genos. ${ }^{181}$ Not long after its ratification, the

8) (arguing that other things being equal, persons with superior natural endowments exhibit greater effort).

178 See, e.g., Fullilove v. Klutznick, 448 U.S. 448 (1980) (sustaining congressional program of affirmative action in public works); Steelworkers v. Weber, 443 U.S. 193 (1979) (approving affirmative action in promotion undertaken by private employers to fulfill obligations under Title VII); University of California Regents v. Bakke, 438 U.S. 265 (1978) (approving affirmative action in university admissions in some circumstances).

${ }^{178}$ In Bakke, Justice Powell wrote for a "majority of one." 438 U.S. at 267. Fullilove was decided by a splintered majority that penned three separate opinions, 448 U.S. at 449 (syllabus), and the decision incited two very strong dissents. See id. at 522 (Stewart, J.), 532 (Stevens, J.). Recently, the Court has construed Title VII as granting only a limited power to the judiciary in ordering affirmative action. Local 28 of Sheet Metal Workers v. E.E.O.C., 106 S. Ct. 3019 (1986) (courts should not use discretion to approve affirmative action simply to create a racially-balanced workforce); Wygant v. Jackson Board of Education, $106 \mathrm{~S}$. Ct. 1842 (1986) (disallowing affirmative action in layoffs to preserve remedies for past discrimination where less intrusive means available); Firefighters Local Union No. 1784 v. Stotts, 467 U.S. 561 (1984) (court cannot extend consent decree affirmative action program to include affirmative action in layoffs in violation of bona fide seniority system).

${ }^{177}$ Even if such a dramatic expansion of affirmative action were feasible, it might impair current aid to those existing minorities who cannot afford the drug.

${ }_{178}$ U.S. Const. art. I, § 9, cl. 8; art. I, § 10, cl. 1. The nobility clauses, however, would not literally be violated unless Congress or a state conferred the noble status upon Genos persons.

179 Still, the prohibitions against titles of nobility are somewhat indeterminate. Note, 94 Harv. L. Rev. at 1858-61 (cited in note 10).

180 U.S. Const. amend. XIII.

181 Nowak, Rotunda, and Young, Constitutional Law at 841 (cited in note 152). But see Laurence H. Tribe, American Constitutional Law 261 (1978) ("in Norwood v. Harrison, the Court was willing to say no more than that 'some private discrimination is subject to special 
Supreme Court construed the thirteenth amendment broadly to eradicate not only slavery but all types of involuntary servitude affecting all persons. ${ }^{182}$ Congress is empowered "to pass all laws necessary and proper for abolishing all badges and incidents of slavery." ${ }^{183}$ Congress is also free to determine rationally what are "badges and incidents of slavery ... [and] translate that determination into effective legislation." 184 Congress may easily come to the conclusion that Genos will produce just such a "badge of slavery." While the drug does not impose a condition of slavery or involuntary servitude in the narrow sense, the drug shackles those who lack it with an extreme and permanent inferiority that offends the minimum equality of condition guaranteed by the thirteenth amendment. ${ }^{185}$ The inequality caused by Genos, like that imposed by the institution of slavery, is practically guaranteed to pass from one generation to the next. ${ }^{186}$

LIBERTAS: The constitutional principle of equality is much

remedial legislation in certain circumstances under $\S 2$ of the Thirteenth Amendment'"), quoting Norwood, 413 U.S. 455, 470 (1973).

${ }^{182}$ The Slaughter-House Cases, 83 U.S. 36, $49-50$ (1873). More recently, the Court has again confirmed that "Congress is authorized under Enforcement Clause of the Thirteenth Amendment to legislate with regard to "every race and individual." " McDonald v. Santa Fe Trail Transp. Co., 427 U.S. 273, 288 n.18 (1976) (citations omitted). The legislative history of the thirteenth amendment sustains this broad reach. Congress intended the amendment, as enforced by the Civil Rights bill of 1866 , to protect all races. G. Sidney Buchanan, The Quest for Freedom: A Legal History of the Thirteenth Amendment, 12 Houston L. Rev. 1, 21 (1974). See also Emily Calhoun, The Thirteenth and Fourteenth Amendments: Constitutional Authority for Federal Legislation Against Private Sex Discrimination, 61 Minn. L. Rev. 313, 355 (1977); Alexander M. Bickel, The Original Understanding and the Segregation Decision, 69 Harv. L. Rev. 1, 11-29 (1955). But compare Note, The Thirteenth Amendment and Private Affirmative Action, 89 Yale L. J. 399 (1979) (construing legislative history of the amendment as protecting black persons, but only white persons who were prejudiced by helping black persons).

${ }^{183}$ Jones v. Alfred T. Mayer Co., 392 U.S. 409, 439 (1968) (emphasis in original).

${ }^{184}$ Id. at 440 . Because Jones involved discrimination against black persons, the Court specifically addressed the historical institution of slavery. As judicial interpretations and the legislative history make clear, however, Congress's power extends to eradicating any badges of slavery against all races. See note 182 above.

Although the precise contours of a "badge or incident of slavery" have not yet been defined, the Supreme Court has held that the concept does comprehend education and employment, interests implicated by Genos. See Runyon, 427 U.S. at 160 (holding that 42 U.S.C. $\$ 1981$ and section two of thirteenth amendment apply to private schools); McDonald, 427 U.S. at 273 (Title VII, enacted in part pursuant to section two of thirteenth amendment, protects employment rights of whites as well as non-whites).

${ }^{185}$ Like its powers under section five of the fourteenth amendment, Congress's powers under section two of the thirteenth amendment to enforce and extend its substantive guarantee may be extremely broad, see notes 253-61 and accompanying text below. However, they may have to be balanced against competing constitutional claims enforced by the courts. See notes $245-52$ and accompanying text below.

${ }^{188}$ See note 198 below. 
abused because it is much misunderstood. Equality of opportunity and absolute equality are two very different notions, but they often are confused. ${ }^{187}$ The latter is in conflict with the constitutional principle of personal liberty; the former is not. To give the constitutional guarantee of personal liberty real value, it is necessary to remove legal barriers to achievement so that all stand on a level playing field. This is equality of opportunity. Absolute equality robs citizens of the benefits of true liberty: the right to be different must include the right to use one's own resources to be "better off" in the eyes of some others. Equality of opportunity may affirm that all women and men are equal in their legal rights, but it does not pretend that they are equal in their natural endowments. Absolute equality would fight natural differences and, in the extreme, make all citizens the same-and thereby make liberty nothing but a hollow platitude. Further, notions of absolute equality are inherently indeterminate: while it is possible to put objective limits upon state-imposed inequality, there is no clear line to be drawn when one attempts to limit the effects of differences in natural ability. ${ }^{188}$

Our constitution embraces equality of opportunity, not absolute equality. ${ }^{188}$ The parts of the Constitution embodying this principle focus on inequality imposed or enforced by the state, not on inequality caused by nature. These provisions eliminate vestiges of slavery, prohibit aristocracies, and protect discrete and insular minorities that are "left out" of the majoritarian political process. Genos does not violate any of these constitutional principles. Nor does it indirectly infringe any of the egalitarian values that these principles embody.

${ }^{187}$ In fact, the notions of removing legal barriers and of equalizing natural potential could be seen as two types of equality of opportunity, types that Aequus's argument conflates. Equalizing natural potential actually moves toward absolute equality.

${ }^{188}$ See Peter Westen, The Empty Idea of Equality, 95 Harv. L. Rev. 537 (1982). Indeed, in a representative democracy, it may be impossible to eliminate all state-imposed inequality of condition; the "representatives" in such a system necessarily enjoy more political "clout" than do ordinary citizens, despite the ideal that citizens are to have equal political power. It is only in idealized "town meeting" democracy or the Aristotelian city state that this inequality would not exist.

${ }^{189}$ For example, James Madison stated that "the protection of different and unequal faculties of acquiring property" is "the first object of government." The Federalist Papers (No. 10) at 78 (New American Library ed. 1961). Most of the founders thought that liberty, including the liberty to benefit from superior talents, was among the rights that formed the basis for equality; they might have considered it ironic to call for liberty's sacrifice in the name of equality. For an elaboration of the view that the Constitution was centrally concerned with preserving the fruits of those with superior natural abilities, see Forrest McDonald, Novus Ordo Seclorum: The Intellectual Origins of the Constitution (1985). 
Genos does not violate the thirteenth amendment. While the amendment may apply to private action like the development and use of Genos, ${ }^{190}$ it may currently protect only black persons, as only their disabilities could be traced to institutional slavery. ${ }^{191}$ Even a broader interpretation of the thirteenth amendment-as encompassing any condition of involuntary servitude-would not render Genos offensive to it. ${ }^{192}$ The drug does not impose involuntary servitude on anyone: it is equally available to all who can afford it.

The nobility clauses prohibit the government from conferring titles of nobility; they do not proscribe private action or natural superiority. Indeed, the history of these clauses evinces that they may have been intended to protect developments like Genos. While the more egalitarian framers may have supported the clauses to prevent domination by particular families, others intended them to ensure that a state-imposed aristocracy based on wealth or position would not impede the ascendancy of persons with greater abilities. ${ }^{193}$ Of course, the opportunity to use Genos does depend on ability to pay, but the Constitution permits differentiation based on wealth. The Court repeatedly has refused to hold that the poor are a "suspect class": it has held that poor people do not have a constitutional right to welfare ${ }^{194}$ or to a particular level of education. ${ }^{195}$

2. Will a Genetically Superior Minority or a Genetically Inferior Majority be Unable to Protect Its Interests in the Majoritarian Political Process?

AEQUUS: Insofar as Genos does not directly offend the equal protection clause and the nobility clauses, Congress may still invoke the policies underlying these clauses to fashion compelling

190 Nowak, Rotunda, and Young, Constitutional Law at 841 (cited in note 152).

192 Note, The "New" Thirteenth Amendment: A Preliminary Analysis, 82 Harv. L. Rev. 1294, 1308 (1969). The disabilities need not have been directly connected to the historical institution of slavery, however. Nowak, Rotunda, and Young, Constitutional Law at 844 (cited in note 152).

${ }^{192}$ Even the most liberal interpretation of the thirteenth amendment as proscribing "second class citizenship" would only proscribe "conditions that could reasonably be called symptoms of a slave society, inability to raise a family with dignity caused by unemployment, poor schools and housing, and lack of a place in the body politic." Note, Jones $v$. Mayer: The Thirteenth Amendment and the Federal Anti-Discrimination Laws, 69 Colum. L. Rev. 1019, 1025-26 (1969). The Court has left open the question of whether section one of the thirteenth amendment by its own operation does anything more than prohibit slavery and involuntary servitude. Consider City of Memphis v. Greene, 451 U.S. 100, 128-29 (1981).

${ }_{193}$ Note, 94 Harv. L. Rev. at 1858-61 (cited in note 10).

184 Dandridge v. Williams, 397 U.S. 471, 485 (1970).

${ }^{105}$ San Antonio School District v. Rodriguez, 411 U.S. 1, 22-23 (1973). 
state interests to ban the drug. Avoiding Genos's assault on the values embodied in the equal protection clause is a compelling state interest. Since Justice Stone's footnote four in United States $v$. Carolene Products Co., the equal protection clause of the fourteenth amendment has been read primarily to protect "discrete and insular minorities" from abuses of their interests by the political process. ${ }^{198}$ Traditional equal protection theory suggests that majorities do not require constitutional protection, as they can protect themselves through the political process. Also, conventional equal protection jurisprudence permits discrimination based on actual ability. ${ }^{197}$

Genos, however, contradicts this accepted wisdom. In essence, it transforms wealth discrimination into a form of racial discrimination. ${ }^{198}$ Moreover, although those who lack the drug will form a political majority, this group's tremendous disadvantage in natural ability will render it more analogous to an insular minority than to a ruling majority. Discrimination predicated on actual differences in ability caused by Genos may be more pernicious than arbitrary distinctions whose injustice is easily perceived. Genos undercuts

${ }^{186} 304$ U.S. 144, 152 n.4 (1938).

187 See generally Massachusetts Board of Retirement v. Murgia, 427 U.S. 307 (1976).

198 Genetically-engineered animals should be regarded as "new species." See note 46 and accompanying text above. Genetically-engineered people would be at least as "different" as are the different races of human beings, perhaps more so. A standard anthropological definition for race is "[a] major division of mankind, with distinctive, hereditarily transmissible characteristics, e.g., Negroid, Mongoloid, and Caucasoid races." Charles Winick, Dictionary of Anthropology 448 (1958).

Genos people by definition have different characteristics. We do not know whether these characteristics are hereditarily transmissible or if pharmacological intervention is required to produce a Genos child in each new generation. Whether Genos is hereditary will depend on whether it affects the germ line. President's Commission at 42 (cited in note 10). Genos may affect the germ line if it is administered during the first several weeks of pregnancy. Id. at 42-48; Hearings at 191-92 (cited in note 38) (testimony of Alexander Capron, Executive Director, President's Commission). If Genos is hereditary, stopping its spread-even if only experimental Genos people exist-may require draconian measures. For simplicity, then, let us assume that Genos is not hereditary. It remains "transmissible," however, because Genos people will have sufficient wealth to purchase the drug for their children and will likely wish to do so.

Another common definition even more clearly marks Genos people as a different "race": "a breeding group with gene organization differing from that of other intraspecies groups." Winick, Anthropology at 448 (cited in this note). The essence of being a Genos person is being bred to have a different genetic structure. "[C]riteria for determining whether characteristics are racial include hereditary transmission, comparative unalterability, lack of variability from external causes, and comparative independence of age and sex." Id. Again, with the possible exception of hereditary transmission, Genos people would possess all of the characteristics necessary to mark them as a distinctive race. With respect to the lack of variability from external causes, the only cause of variation in Genos people is the effect of Genos itself. 
most of the traditional reasons given for the moral acceptance of rewards based on superior ability-in particular, exertion of effort and uncontrollable luck in heredity. Genos rewards existing wealth with fantastic ability and the potential to realize even more wealth. ${ }^{198}$ With increasing wealth will come increasing political power. The morally arbitrary nature of this spiral of success may understandably kindle feelings of envy or resentment among the majority that lacks the drug. ${ }^{200}$

Nevertheless, there may be little the non-Genos majority can do outside the political arena to counteract the disadvantages ensured by the drug. Concerted refusal to deal with the Genos minority may have significant redistributive effects in favor of non-Genos people. ${ }^{201}$ But ad hoc, private discrimination against Genos people will be discouraged by practical economics: Genos people will be valuable assets to most enterprises. ${ }^{202}$ In addition to the myriad practical difficulties with private efforts to discriminate against Genos people, the current legal system disfavors the requisite collusive practices and may also bar private employment dis-

199 Indeed, due to preexisting deprivations, traditional minorities may disproportionately populate the non-Genos stratum. In contrast to existing types of discrimination, that spawned by Genos may irreversibly subordinate minorities. Just as economically disadvantaged members of traditional minorities are not constitutionally entitled to welfare or a certain quality of education, likely they also are not entitled to Genos. See Dandridge, 397 U.S. at 485 (holding that the poor are not a suspect class and that they have no constitutional right to welfare); Rodriguez, 411 U.S. at 22-23 (poor have no right to particular quality of education).

200 John Rawls excuses envy engendered by a relative imbalance in the distribution of "primary goods." Rawls, A Theory of Justice at 62 (cited in note 8). He also contrasts envy with resentment, which "is a moral feeling. If we resent our having less than others, it must be because we think that their being better off is the result of unjust institutions or wrongful conduct on their part." Id. at 533. Accordingly, one might conclude that because superior ability may result naturally as well as from Genos effects, the drug gives no cause for resentment. But the metamorphosis effectuated by Genos is singularly dramatic and most likely permanent.

${ }^{201}$ For example, the redistributive impact of concerted racial discrimination disadvantages the black minority. Posner, The Economics of Justice at 355 (cited in note 4).

${ }^{202}$ Judge Richard Posner notes that refusing to do business with a particular group due to racial or other discrimination places a firm at a competitive disadvantage compared to firms who do not so discriminate. Id. at 351-52. Of course, if the firm would lose more business-in particular, that of the racial majority-for shunning discrimination, it might refuse to deal with the minority. However, refusals to deal with enormously able Genos people may prove far more expensive than refusals to deal with more typical individuals. Aside from the potential legal and practical problems of enforcing agreements against hiring these economically advantageous people, the threat that Genos people will establish their own, more productive businesses may deter such agreements. To avert such developments, collusion against Genos people would have to extend to almost all business dealings. If $\mathrm{Ge}$ nos people were excluded from the domestic marketplace, they might just move to more hospitable counties. 
crimination against them. ${ }^{203}$

Political action thus may be the majority's only adequate defense against Genos. Progressive taxation might be used to recapture some of the wealth that Genos people garner. But if the political power of Genos people is commensurate with their wealth and ability, this remedy also may be difficult. Any regulation that discounts the interests of Genos people may encounter stiff opposition in a government in which they are amply represented. The sway that Genos public officials could give to their electorates will make them attractive candidates. Once Genos people occupy the elected or appointed corridors of power, they may be there to stay. The only means of shielding the majority from this menace of permanent status as a economic and political underclass is to stop the stratification before it comes into being-by banning Genos.

But legislation restricting Genos or Genos people poses thorny fourteenth amendment problems. If majoritarian political action against Genos people were to succeed, legislation aimed against them would present the Supreme Court with a Hobson's choice: condoning such laws would sanction a kind of genetic apartheid, while invalidating them would leave the majority defenseless to protect itself.

The problem is difficult but not impossible to resolve. Genos people possess some of the classic characteristics of a suspect class: they are a minority, and by assumption, they possess immutable physical characteristics that render them discrete to facilitate discrimination. ${ }^{204}$ Importantly, these same immutable differences like-

${ }^{203}$ If they are directed at changing the social, political, or economic structure, boycotts against Genos people may receive constitutional protection. See NAACP v. Clairborne Hardware Co., 458 U.S. 886 (1982); Prosser \& Keeton at 1025-26 (cited in note 116). If the purpose of the boycott is to garner competitive advantage in the marketplace, however, the doctrine of concerted refusal to deal will likely provide causes of action under both antitrust and tort. Id. at 1013-15, 1023-26; Lawrence Antony Sullivan, Handbook of the Law of Antitrust 261-65 (1977). Boycotts in which the business competitors of Genos people participate will likely fall into the prohibited category. Prosser \& Keeton at 1024-26 (cited in note 116); Sullivan, Antitrust at 261-62 (cited in this note). Incidentally, some of these protections would also proscribe collusion among Genos people both in their business practices and in any attempts to limit sales of Genos to transactions between each other.

Further, Title VII remedies for race discrimination could conceivably be applied to Genos people, see John B. Attanasio, Equal Justice Under Chaos: The Developing Law of Sexual Discrimination, 51 Cin. L. Rev. 1, 3 n.14 (1982) (Title VII indicates a broad, remedial purpose), and would proscribe discriminating against Genos people in matters of employment. Carving out a statutory exception to permit discrimination against Genos people may be unconstitutional.

${ }^{204}$ Even if they did not possess distinguishing physical characteristics, discrimination could readily proceed against Genos people. Their mental and physical capabilities would clearly reveal their identity. 
wise mark non-Genos people as a discrete group, if not a minority. While Genos people obviously cannot demonstrate a history of discrimination, ${ }^{205}$ such a history might quickly evolve if Congress and state legislatures begin enacting restrictions against them. On the other hand, if Genos people become politically powerful, they might soon enact laws that may adversely affect the non-Genos majority. ${ }^{206}$ Thus, the question is whether Genos people or nonGenos people are most like a "discrete and insular minority."

The possibility of declaring Genos people a suspect class poses a perplexing question: does the law afford special protection to a group that has vast inherent superiority? The Court likely would protect a traditional racial or ethnic group even though statistics revealed a stunning history of success.

If the fourteenth amendment is construed to protect Genos people against political action by the non-Genos majority, this will strip the non-Genos majority of any hope of political remedies against domination by the superior minority. The ultimate paradox of Genos then will be to reduce the majority to the political equivalent of a discrete and insular minority. Once the drug is produced, non-Genos people will practically and constitutionally be unable to protect themselves through the political process. Consequently, the majority must be allowed to protect itself by banning the drug while it still can. These egalitarian interests should not be ignored simply because non-Genos people will constitute a majority: witness the fourteenth amendment protection of women. ${ }^{207}$

Alternatively, the Court might acknowledge the egalitarian interests of the non-Genos majority by treating as suspect all racial classifications-even if they operate against a political majority. Justice Powell's swing opinion in University of California Regents v. $B a k k e^{208}$ rejected purposeful race-based discrimination in educa-

${ }^{203}$ A history of discrimination probably is required to trigger heightened equal protection scrutiny. See, e.g., Murgia, 427 U.S. at 313. For example, the history of discrimination against women in large part has led to heightened scrutiny of gender-based classifications. See Frontiero v. Richardson, 411 U.S. 677, 684-88 (1973).

However, while a group might not qualify for the strongest equal protection guarantees unless it can show a history of discrimination, the equal protection clause demands that any classification be based at a minimum on a rational relation to a permissible state purpose. See, e.g., U.S. Dept. of Agriculture v. Moreno, 413 U.S. 528 (1973) (bare desire to harm a politically unpopular group is impermissible).

${ }^{208}$ Laws against the non-Genos majority may not directly discriminate against it as much as legally protect the natural advantages afforded by the drug.

${ }^{207}$ See, e.g., Heckler v. Mathews, 465 U.S. 728, 744-45 (1984) (subjecting gender discrimination to heightened scrutiny).

${ }^{208} 438$ U.S. 265, 269-320 (1978). Justice Powell would permit affirmative action in some cases on first amendment grounds of educational diversity. Id. at 311-15. However, he 
tion, even where it operates against the white majority to redress the continuing inequities that black persons endure. Use of Genos will disadvantage the non-Genos majority for purposes far less worthy than redressing the deep disadvantages of black persons. ${ }^{209}$ Plyler $v$. Doe $e^{210}$ suggests yet another equal protection interest that the Court may find compelling: avoiding the creation of a subclass or "caste" in American society. ${ }^{211}$ Those who lack Genos could become just such a permanent underclass.

LIBERTAS: Footnote four of Carolene Products suggests the equal protection clause focuses on protecting discrete and insular minorities, not majorities like non-Genos people. ${ }^{212}$ Moreover, the mandates of the equal protection clause are activated only if there is both state action ${ }^{213}$ and discriminatory purpose. ${ }^{214}$ Private corporations manufacture Genos. They presumably do so to make profits and not for the purpose of increasing the inequalities in society. Individuals likewise choose to use Genos to make themselves better off, not necessarily to make others (absolutely or relatively) worse off.

Non-Genos people lack most of the distinguishing characteris-

joined in striking down the quota at issue in Bakke. Id. at 315-20.

${ }^{209}$ Affirmative action for historically deprived minorities could still pass even the strict scrutiny test because rectifying a particular history of discrimination constitutes a compelling state interest. There are also other rationales for upholding affirmative action. See Fullilove, 448 U.S. at 495 (Powell, J., concurring) (section two of the thirteenth amendment and section five of the fourteenth amendment); Bakke, 438 U.S. at 311-15 (first amendment interest in educational diversity). Nonetheless, affording majorities constitutional protection against racial discrimination can adversely affect minorities. For example, in Wygant, $106 \mathrm{~S}$. Ct. at 1842, Powell wrote for a plurality of four Justices in striking down an affirmative action plan. He rejected the plan because it operated without any finding that the individuals benefited had personally suffered from discrimination and because the plan gave preferences to blacks in layoffs, which was regarded as more intrusive than preferential hiring. Id. at 1849.

210457 U.S 202 (1982).

${ }^{211}$ Id. at 213,223 . Two concurring opinions also expressed fears concerning the creation of a subclass of illiterate, illegal immigrants. Id. at 233 (Blackmun, J., concurring), 23839 (Powell, J., concurring). For two interesting caste analyses of racial discrimination not specifically pertaining to the Plyler context, see Paul R. Dimond, The Anti-Caste Principle-Toward a Constitutional Standard for Review of Race Cases, 30 Wayne L. Rev. 1 (1983); Owen Fiss, Groups and the Equal Protection Clause, 5 Phil. \& Pub. Affairs 107 (1976).

212304 U.S. at 152 n.4.

${ }^{213}$ Shapiro, 48 So. Cal. L. Rev. at 367-68 (cited in note 10). Since that article was written, the Court has considerably narrowed the definition of state action. See, e.g., Blum v. Yaretsky, 457 U.S. 991 (1982) (no state action for state-imposed penalties for alleged failure to effect medically appropriate releases from nursing homes); Rendell-Baker v. Kohn, 457 U.S. 830 (1982) (no state action for employee discharge from extensively regulated private school when state did not specifically regulate school's employment practices).

${ }^{214}$ See, e.g., Washington, 426 U.S. at 229. 
tics of discrete and insular minorities. First, they form a substantial political majority. The Constitution does not guard the egalitarian interests of a majority that can defend itself in the political process. It is more credible to think that it is the Genos people who will need constitutional protection from the political actions of the majority-actions such as attempts to eradicate them by banning Genos. Plyler, Bakke, and the gender discrimination cases all manifest some ambivalence about affording countermajoritarian protection to a popular majority even when there has been a history of discrimination. For example, the Court has subjected gender-based classifications to "heightened," not "strict," scrutiny;"215 and a majority of the Court has never accepted Justice Powell's conclusion in Bakke that even classifications disadvantaging the racial majority are subject to strict scrutiny. ${ }^{\mathbf{2 1 6}}$

Second, non-Genos people as a group obviously have not already experienced a history of purposeful unequal treatment, nor have they been stereotyped to mask their true abilities. ${ }^{217}$ Plyler, $B a k k e$, and the gender discrimination cases all turn on clear evidence of past discrimination. ${ }^{218}$ In contrast, the supposed powerlessness of non-Genos people is pure speculation, and speculative harms do not provide a sound constitutional basis for invoking the power of the state to constrain free choice. It is, for example, hard to believe that the non-Genos majority ever would face disadvantages comparable to those faced by black persons throughout American history, or by the children of illegal immigrants in Plyler.

Third, any advantages that the non-Genos majority suffers relative to Genos people will be based on actual ability-unlike the disadvantages imposed on racial or ethnic groups, or on women.219 Some discrimination in favor of Genos people is both inevitable and good; recognizing and rewarding the use of their superior capabilities will benefit all of society. Further, Genos people may them-

21s See generally Attanasio, 72 Geo. L. Rev. at 1689 (cited in note 66).

216 Only Justice Powell applied strict scrutiny to classifications disadvantaging groups that were not discrete and insular minorities. 438 U.S. at 287-305. In Fullilove v. Klutznick, the dissents of Justices Stewart and Stevens embrace the view that the equal protection clause is color blind, so that classifications disadvantaging whites are treated no more favorably than classifications disadvantaging blacks. 448 U.S. at 522 (Stewart, J.), 532 (Stevens, J.).

217 Murgia, 427 U.S. at 313.

218 See Frontiero, 411 U.S. at 677; Bakke, 438 U.S. at 360-61 (Brennan, J., concurring in part and dissenting in part); Nowak, Rotunda, and Young, Constitutional Law at 713-14 (cited in note 152); Tribe, American Constitutional Law at 1060 (cited in note 181).

210 Murgia, 427 U.S. at 313. 
selves mitigate any problems produced by their superior status: the well-off generally have a rational self-interest in alleviating inequality by redistributing some of the increased resources they generate. ${ }^{220}$

Compelling state interests cannot rest on speculation. After Genos becomes available, a long period of time will elapse before a sound determination can be made that the harm the drug produces sufficiently outweighs its benefits to create a compelling state interest in controlling its use.

3. Can Congressional Powers to Safeguard Both Libertarian and Egalitarian Values Avert a Collision of Constitutional Principles?

AEQUUS: Congress has powers to broaden the scope of traditional fourteenth amendment jurisprudence. Even if egalitarian arguments asserted against Genos do not reflect constitutional mandates that the judiciary is bound to enforce, Congress can expand the constitutional demand of equality by exercising its powers under section five of the fourteenth amendment. ${ }^{221}$ Significantly, the Supreme Court has recently indicated that Congress can apply section five of the fourteenth amendment to prohibit discrimination that is not purposeful. ${ }^{222}$ Moreover, Congress can invoke this power to regulate purely private conduct. In United States $v$. Guest, ${ }^{223}$ six Justices specifically stated that section five empowered Congress to regulate purely private conduct. ${ }^{224}$ The Court reaffirmed this principle in District of Columbia $v$. Carter. ${ }^{225}$ While declaring that, on its face, the fourteenth amendment does not regulate private conduct, the Court added this caveat: "This is

220 Posner, The Economics of Justice at 89-90 (cited in note 4).

221 "The Congress shall have the power to enforce, by appropriate legislation, the provisions of this article." U.S. Const. amend. XIV, § 5. The Supreme Court has held that Congress cannot use its section five power to dilute the scope of constitutional protections. Mississippi University for Women v. Hogan, 458 U.S. 718, 732-33 (1982); Katzenbach v. Morgan, 384 U.S. 641, 651 n.10 (1966). Accordingly, section five would not empower Congress directly to countermand a judicial holding that Genos violates the guarantee of liberty. Congress possibly could recognize a countervailing equal protection interest against Genos-although it is not clear how that interest should be balanced against the liberty interest, if any, in taking the drug.

${ }^{222}$ See City of Rome v. United States, 446 U.S. 156, 176-77 (1980) (dispensing with the requirement of discriminatory intent for congressional legislation under section two of the fifteenth amendment and analogizing this to cases decided under section five of the fourteenth amendment). See also Fullilove, 448 U.S. at 476-77 (plurality opinion for two members of the Court).

${ }^{223} 383$ U.S. 745 (1966).

224 Id. at 762 (Clark, J., concurring), 782-84 (Brennan, J., concurring and dissenting).

225409 U.S. 418 (1973). 
not to say, of course, that Congress may not proscribe purely private conduct under the fourteenth amendment."226

The section five power appears to be broad enough to allow Congress to declare that the manufacture of Genos violates equal protection. In particular, section five allows Congress broad power to remedy violations of Court-declared equality interests and to define new classes of equality interests. In Katzenbach v. Morgan, ${ }^{227}$ the Supreme Court held that section five empowers Congress to designate and proscribe conduct as violative of equal protection, even if that conduct has not been identified as a violation by the courts. The uncontroversial part of the Morgan holding is that Congress is empowered to enforce equal protection requirements that the Court already has identified-for example, the guarantee against racial and ethnic discrimination. Thus, the Court recognized congressional authority to determine that the right to vote would endow Puerto Ricans with the necessary political power to overcome discrimination against them in governmental services. ${ }^{228}$ Deference to Congress in making this judgment is exceptional. ${ }^{229}$

Chief Justice Burger's plurality opinion in Fullilove v. Klutznick $^{230}$ likewise gives Congress broad discretion as to how to enforce those equal protection mandates that the Court has already established. ${ }^{231}$ Significantly, the Chief Justice's opinion also permits Congress to forestall prospective infringements on the guarantee of equal protection by allowing remedial measures to apply to new programs, in which findings of specific past discrimination

228 Id. at 424 n.8 (emphasis added). See also Archibald Cox, The Supreme Court, 1965 Term-Foreword: Constitutional Adjudication and the Promotion of Human Rights, 80 Harv. L. Rev. 91, 114 (1966) (arguing that modern conditions and political philosophy require that section five empower Congress affirmatively to advance "material welfare and human rights").

${ }^{227} 384$ U.S. 641, 652-56 (1966) (upholding federal legislation prohibiting state-imposed English literacy requirements that impeded the right of Puerto Rican citizens to vote).

228 Id. at $652-53$.

229 "It is not for us to review the congressional resolution of [the various conflicting] factors." Id. at 653. Archibald Cox notes that the Morgan decision lacks even token qualifying phrases on Congress' judgment such as "rational." Cox, 80 Harv. L. Rev. at 104 (cited in note 226).

230448 U.S. 448 (1980).

2s1 Congress, after due consideration, perceived a pressing need to move forward with new approaches in the continuing effort to achieve the goal of equality of economic opportunity. In this effort, Congress has necessary latitude to try new techniques . . . to accomplish remedial objectives.

448 U.S. at 490 (1980). 
obviously are impossible. ${ }^{232}$ In this connection, Congress could simply predicate its remedial measures on the general history of discrimination against the various minorities involved.

The racial discrimination that Genos spawns ${ }^{233}$ is at the heart of judicially established equal protection interests. Consequently, Morgan enables Congress to act based on its speculations about the drug's possible effects, and Fullilove allows projections about the drug even though it is a new development.

The irreversibility of the Genos decision requires that Congress be given this authority at an early stage. Although Congress lacks a specific history of discrimination fostered by Genos upon which to predicate its conclusions, it does possess ample experience with discrimination against minorities and majorities (affirmative action and gender discrimination) with which to evaluate the drug. Considering the painful and ignominious experience our nation has had with other forms of discrimination, Congress should be able to avert the creation of new suspect classifications involving race.

Another part of the Morgan holding goes beyond empowering Congress to remedy categories of equal protection violations declared by the Court: it recognizes Congress's authority to designate new categories of equal protection violations in addition to those that the Court has established. Indeed, the Court in Morgan held that Congress could determine-independent of racial discrimination and despite a prior contrary holding by the Court-that English literacy tests were a per se violation of the equal protection clause. ${ }^{234}$ On this point, the Court simply opined: "We perceive a basis upon which Congress might predicate a judgment that the application of New York's English literacy requirement . . . constituted an invidious discrimination in violation of the Equal Protection Clause."2ss

Invoking this authority, Congress could ban Genos as a violation of equal protection, and a reviewing court could easily "perceive a basis" for this legislative determination. Congress reasonably could conclude that the use of Genos by the rich will

232 Id. at $480-81$.

${ }^{233}$ Genos-based discrimination can be seen as race discrimination. See note 198 and accompanying text above.

2s4 384 U.S at 653-56. See also Nowak, Rotunda, and Young, Constitutional Law at 834-35 (cited in note 152).

235 384 U.S. at 656 . Finding the second part of Morgan's holding "a strikingly novel form of judicial deference to congressional power," Archibald Cox construes it as holding that "Congress may decide, within broad limits, how the general principle of equal protection applies to actual conditions." Cox, 80 Harv. L. Rev. at 106 (cited in note 226). 
perpetuate and exacerbate the disadvantage suffered by the poor and that such inequality can be remedied under section five. Alternatively, it could also conclude that the drug will engender a new divisive form of racial separation.

LIBERTAS: Congress's power under section five of the fourteenth amendment is not a blank check. Section five does not apply to purely private conduct. In the Civil Rights Cases of $1883,{ }^{236}$ the Supreme Court explicitly held that the fourteenth amendment does not confer upon Congress the power to regulate private conduct. Guest does not suggest that Congress could invoke section five to regulate all private conduct: the particular conduct at issue in that case interfered with the exercise of public rights. ${ }^{237}$ Thus, if it permits Congress to regulate private conduct at all, section five only permits regulation of private conduct that specifically interferes with the exercise of public rights. Genos involves no such interference.

Even granting that section five might allow congressional regulation of private conduct, Morgan does not eliminate the requirement that Congress have some evidence of past discrimination to act against private conduct (although the case may relax the requirement somewhat). Such evidence was the basis for applying Morgan's rationale in Fullilove. ${ }^{288}$ Morgan and Fullilove may allow Congress to act to forestall prospective discrimination in new programs without an extensive record of past discrimination. ${ }^{238}$ But this does not suggest that Congress can act without any evidence of discrimination. Even if discrimination against non-Genos persons qualifies as racial discrimination, Congress will be entitled to act against Genos only when some such discrimination actually occurs. ${ }^{240}$

While the powers Morgan gives to Congress may extend to identifying and remedying equal protection violations by the states, they do not necessarily permit Congress to define new categories of equal protection. The limits on congressional power were made clear in Oregon $v$. Mitchell, in which the Court allowed Con-

236 109 U.S. 3, 23 (1883) (section two of the thirteenth amendment can regulate purely private conduct, but section five can only counteract and afford relief against state regulations or proceedings). See also United States v. Harris, 106 U.S. 629 (1882).

${ }^{237}$ See Tribe, American Constitutional Law at 273-74 (cited in note 181). The specific conduct involved in Guest was interference with the exercise of fourteenth amendment rights.

238 Fullilove, 448 U.S. at 476.

239 Id. at $476-78$.

240 Morgan, 384 U.S. at 657-58. 
gress to use section five to lower the minimum voting age for federal elections, but not for state elections. ${ }^{241}$ In Mitchell, four Justices specifically rejected the power of Congress to define the substantive requirements of equal protection. ${ }^{242}$ This conclusion conforms with the principle of separation of powers: it must be the Court, not Congress, which ultimately interprets the equal protection clause. ${ }^{243}$ Since Mitchell, the Court has not allowed Congress independently to define equal protection. ${ }^{244}$ Were Congress to attempt to redefine the scope of the equal protection clause in order to ban Genos, it could not claim that its actions were immune from judicial review.

Further, when congressional action against Genos is reviewed by the courts, Congress's justifications need not be given great deference. The regulation of Genos may place the fourteenth amendment command of equal protection in direct conflict with the principles of individual liberty embodied in the same amendment. Even if Congress can posit a credible egalitarian interest against Genos, it may not abrogate the fourteenth amendment liberty interest in taking the drug. ${ }^{245}$ What results is a collision between "liberty" as it is recognized and protected by the countermajoritarian Court and "equality" as defined by the majoritarian legislature.

Which body has ultimate responsibility for the resolution of this tension? Notwithstanding any power Congress might possess under section five of the fourteenth amendment, the judiciary is the final arbiter of the Constitution; legislatures cannot make laws

241400 U.S. 112 (1970).

${ }^{242}$ Id. at 293-96 (Stewart, J., concurring in part and dissenting in part), 201-09 (Harlan, J., concurring in part and dissenting in part). See generally Samuel Estreicher, Congressional Power and Constitutional Rights: Reflections on Proposed "Human Life" Legislation, $68 \mathrm{Va}$. L. Rev. 333, 426-38 (1982). Casting the deciding vote in Mitchell, Justice Black resolved the case on the narrow ground that the Constitution specifically empowers the states to regulate their own elections. 400 U.S. at 124-30.

${ }^{243}$ See Marbury v. Madison, 5 U.S. 137, 177 (1803).

244 Estreicher, $68 \mathrm{Va}$. L. Rev, at 438 (cited in note 242). Recently, four dissenting Justices in E.E.O.C. v. Wyoming, 460 U.S. 226 (1983) rejected the use of the section five power to apply age discrimination proscriptions against the states. Citing Murgia, 427 U.S. at 307, and Vance v. Bradley, 440 U.S. 93 (1979), these Justices noted that the Court had declared age discrimination beyond the pale of the equal protection clause. 460 U.S. at 259-63 (Burger, C.J., dissenting). The plurality rested Congress's authority to enact such proscriptions on the commerce clause and declined to address whether the legislation could be upheld under section five. Id. at $243 \&$ n. 18 .

${ }^{245}$ See Hogan, 458 U.S. at 732, which cited Morgan, 384 U.S. at 651 n.10, and concluded that Congress may enforce, but not dilute, the equal protection guarantee. The conclusion suggests that Congress likewise may not define equal protection so as to dilute the guarantee of individual liberty. 
that fly in the face of the Court's interpretation of the Constitution. ${ }^{246}$ The Court cannot foresake individual rights by deferring to the majoritarian legislative process. $^{247}$ The judiciary can and should resolve the conflict, removed from political gales and in a reasoned fashion. ${ }^{248}$ Justice Robert Jackson proclaimed:

The very purpose of a Bill of Rights was to withdraw certain subjects from the vicissitudes of political controversey [sic], to place them beyond the reach of majorities and officials and to establish them as legal principles to be applied by the courts. One's right to life, liberty, and property, to free speech, a free press, freedom of worship and assembly, and other fundamental rights may not be submitted to vote; they depend on the outcome of no elections. ${ }^{249}$

The Court has resolved conflicts between liberty and equality before. With Genos, the only real problem is unequal access to the drug based on wealth, but wealth disparities count for little in constitutional jurisprudence. ${ }^{250}$ The Court historically has rejected claims based on economic inequality when faced with competing liberty claims. ${ }^{251}$ For example, when Congress passed legislation limiting campaign expenditures in order to equalize access to political candidacy, the Court invalidated the limits on the ground that they infringed on the first amendment liberty to speak. ${ }^{252}$

AEQUUS: Oregon v. Mitchell does not repudiate Congress's authority to construe and expand the equal protection guarantee; on the contrary, the decision reaffirms that authority. Four Justices clearly approved Congress's discretion in this area, ${ }^{253}$ and the pivotal opinion of Justice Black substantially upheld it. ${ }^{254}$ Because

248 Cooper v. Aaron, 358 U.S. 1, 18 (1958); Marbury, 5 U.S. at 177.

${ }^{247}$ David A. J. Richards, Taking Taking Rights Seriously Seriously: Reflections on Dworkin and the American Revival of Natural Law, 52 N.Y.U. L. Rev. 1265, 1328 (1977).

${ }^{245}$ See Guido Calabresi and Philip Bobbitt, Tragic Choices 67 (1978).

210 West Virginia State Bd. of Education v. Barnette, 319 U.S. 624, 638 (1943).

${ }^{280}$ The Court has refused to recognize poor people as constituting a suspect class and has rejected the notion that citizens have a right to welfare. Dandridge, 397 U.S. at 485 . It has also rejected the claims of poor women that a state may not refuse to fund abortions when it provides funding for other medical services. Maher, 432 U.S. at 471-74.

${ }^{251}$ See notes 6-7 above; Nowak, Rotunda, and Young, Constitutional Law at 731-34 (cited in note 152).

232 Buckley, 424 U.S. at 39-59 (per curiam).

2s3 400 U.S. at 141-44 (Douglas, J., concurring in part and dissenting in part), 246-49

(Brennan, J., White, J., and Marshall, J., concurring in part and dissenting in part).

254 Since Congress has attempted to invade an area preserved to the States by the Constitution without a foundation for enforcing the Civil War Amendments' ban on racial discrimination, I would hold that Congress has exceeded its powers in attempting to 
the effects of Genos will foster racial discrimination and because regulation of medical technology is not exclusively reserved to the states (thus avoiding the federalism problems Justice Black saw in Mitchell,) the Court should uphold congressional authority to ban the drug under section five.

Institutional considerations also argue in favor of a congressional prerogative to define the scope of the fourteenth amendment. Institutional constraints may impede the federal courts from enforcing constitutional norms to their fullest extent. To compensate for this judicial underenforcement, Congress is rightly empowered to push constitutional guarantees to their limit. ${ }^{255}$ Unlike the Court, Congress need neither articulate principles nor adhere to precedent. ${ }^{258}$ Moreover, Congress can make pragmatic distinctions that may be "either rough or finely tuned."287 Congress's superior fact-finding ability allows it to define new categories of equal protection violations, ${ }^{258}$ as well as to remedy violations previously defined by the Court. Even if the egalitarian interests implicated by Genos are not readily cognizable under traditional equal protection theory, ${ }^{259}$ the myriad concerns that Genos raises make deference to Congress's decisionmaking ability particularly appropriate. ${ }^{260}$

Conflict between libertarian and egalitarian values in the fourteenth amendment need not always be resolved in favor of personal liberty. For example, the Supreme Court has allowed the

lower the voting age in state and local elections. On the other hand, where Congress legislates in a domain not exclusively reserved by the Constitution to the States, its enforcement power need not be tied so closely to the goal of eliminating discrimination on account of race.

Id. at 130.

${ }^{25 b}$ Lawrence Gene Sager, Fair Measure: The Legal Status of Underenforced Constitutional Norms, 91 Harv. L. Rev. 1212, 1239-40 (1978). Sager would not permit congressional enforcement to undercut constitutional norms propounded by the Court. Id. at 1240 . However, Genos is a novel issue ranging well beyond established norms. 112.

${ }^{258}$ Robert A. Burt, Miranda and Title II: A Morganic Marriage, 1969 S. Ct. Rev. 81,

${ }^{287}$ Henry P. Monaghan, The Supreme Court, 1974 Term-Foreword: Constitutional Common Law, 89 Harv. L. Rev. 1, 28-29 (1975).

${ }^{268}$ Cox, 80 Harv. L. Rev, at 107 (cited in note 226).

258 See notes 204-11 and accompanying text above.

${ }^{280}$ See Irving A. Gordon, The Nature and Uses of Congressional Power Under Section Five of the Fourteenth Amendment to Overcome Decisions of the Supreme Court, 72 N.W. U. L. Rev. 656, 699 (1977):

[F]ederal courts probably do not have the fact-finding machinery and the expertise to cope with [the far reaching consequences of imponderables like school financing reforms] as thoroughly and comprehensively as another branch of the government, and ... the solutions of some of these problems require difficult and perhaps inconsistent policy choices and compromises which the Court might not be able to make in principled fashion. 
government to subordinate the liberty interests in free exercise of religion and free association to egalitarian goals of racial and gender integration. ${ }^{261}$

\section{Alternative Distribution Schemes: Are There Less Restrictive Means of Satisfying Egalitarian Interests?}

LIBERTAS: Even if the Court decides with respect to Genos that egalitarian interests outweigh liberty interests, Congress nevertheless has only limited discretion to choose the means of regulating Genos. Egalitarian restrictions on Genos implicate fundamental personal and reproductive liberties and constitute preemptive discrimination that would eliminate a future race. In light of these important liberty interests, Congress must prove that the limits it places on Genos are the least restrictive means necessary to effectuate its egalitarian ends. ${ }^{262}$

Means far short of an absolute ban may be sufficient to meet egalitarian ends. In fact, it may prove not to be so difficult for the average person to pay to receive Genos. If the drug does produce people of superior capacity, it will produce superior economic performance. Lenders will find it profitable to provide funds to those who could not otherwise afford Genos if, through its use, the borrowers' offspring have particular promise. When that promise bears fruit, Genos offspring will be able to use their increased earnings to pay off the loans required to augment their productive potential.

Such a system of private selection and funding of Genos users may prove to be more accurate than government regulation in targeting those members of American society-from among both the advantaged and the disadvantaged-who will profit most from the use of Genos. The free market may not only be more efficient than regulation at selecting those who should have access to the limited supply of Genos; it may be more equitable as well. Government agencies often are "captured" by special interests that subvert the interests of the general public and use government control

${ }^{261}$ Bob Jones University, 461 U.S. at 604 (upholding IRS denial of tax deductions to racially discriminatory religious university); Runyon, 427 U.S. at 175-76 (racial integration takes precedence over free association rights of private school students and their parents); Roberts, 468 U.S. at 609 (ordering men's association to admit women to membership, in the face of free association claim).

${ }_{262}$ Tribe, American Constitutional Law at 1000-01 (cited in note 181). Korematsu v. United States, 323 U.S. 214 (1944), is the rare example when the Court has sustained government regulations based on an explicit racial or ethnic classification. Tribe, American Constitutional Law at 1000. 
as their own special sword and shield. ${ }^{263}$

If the private market fails to produce an efficient or fair distribution of Genos, very limited government intervention may address whatever problems remain. The government could allow the market generally to allocate the drug but could subsidize its use directly among the poor. Alternatively, the government itself could distribute Genos among potential users, charging prices that vary according to wealth. ${ }^{264}$ Direct subsidies or egalitarian distribution of Genos by the government also would mitigate long-run concerns about propagating an elitist class system. Genos persons dispersed among various economic and social classes would have the opportunity to help others of their group.

Even these limited egalitarian distribution schemes will impair fundamental liberty rights. Because Genos is in limited supply, some who could afford the drug will not receive it. The deprivation of the liberty of these people must be kept to the minimum truly necessary to accommodate actual egalitarian interests. ${ }^{265}$

AEQUUS: When it acts under section five of the fourteenth amendment, Congress need not show that its regulation of Genos is no more restrictive than necessary to effectuate egalitarian interests. $^{268}$ Even if this were a requirement, banning Genos altogether may be the only feasible means of protecting the egalitarian interests that the drug threatens. Profound egalitarian and even libertarian problems infect the various distribution alternatives.

Market solutions are particularly questionable. Financing Genos through loans is both impractical and offensive. Pregnancy entails certain risks. To obtain a Genos loan, would the mother have to undergo tests prescribed by the lender? Would the agreement carefully circumscribe the activities of the mother during pregnancy and of both parents and child during child rearing? Could

${ }^{26 s}$ See Richard A. Pọner, Taxation by Regulation, 2 Bell J. Econ. \& Mgmt. Sci. 22 (1971). See also Sam Peltzman, Toward a More General Theory of Regulation, 19 J. L. \& Econ. 211 (1976) (setting forth an economic model of regulatory agency "capture"); Richard A. Posner, Theories of Economic Regulation, 5 Bell J. Econ. \& Mgmt. Sci. 335 (1974) (discussing and criticizing the "capture" theory of regulation); George J. Stigler, The Theory of Economic Regulation, 2 Bell J. Econ. \& Mgmt. Sci. 3 (1971).

204 Calabresi and Bobbitt, Tragic Choices at 101-02 (cited in note 248). Congress could subsidize the cost of Genos to lower income groups.

${ }^{205}$ Price, or some combination between price and time, could serve as differentiating factors. Id. at 92-95. An example of such a combination would be waiting one's turn in line when price is set well below the market rate. Beyond a certain minimal level, governmental determination of "fit" Genos parents should be viewed with suspicion.

288 The Chief Justice's plurality opinion in Fullilove exhibited a willingness to defer to Congress's selection of affirmative action as a means of enforcing the equal protection guarantee. 448 U.S. at 472. 
the parents obligate the child to pay off the loan? On one level, Genos loans would transform Genos people into slaves or capital assets. These questions illustrate the extent to which Genos recasts human beings into products.

Further, it is unlikely that the free market will be able to sort out "good" Genos investments from "bad" and thereby make the drug available to the poor through loans. It is unlikely that many lenders will be willing to take the risks involved in making loans to poor parents for the use of an untested technique to improve the productivity of their offspring. Even if there are willing lenders, they may believe that the easiest way for them to tell a "good" Genos risk from a "bad" one is by evidence of the parents' prior social and economic success.

Private producers might be required to vary prices according to wealth. But this also poses problems. The supposedly wealthneutral market will still discriminate in favor of more wealthy individuals within each designated category. Moreover, differential subsidies will spark bitter debate about who receives the greater subsidy.

To cure problems of wealth-related distributions, the government might itself allocate Genos using standards other than wealth; however, the choice and application of these other standards are problematic. For example, the government could distribute the drug to particularly intelligent parents. But intelligence is difficult to define, is significantly influenced by heredity, ${ }^{267}$ and arguably is as arbitrary a standard as wealth. ${ }^{268}$ It may be impossible for the government to find any distribution criteria "which are both lucid and inoffensive to our egalitarian beliefs." would be more neutral; but even this would be inegalitarian if some people-perhaps those lacking certain physical and mental capabilities-were excluded from the drawing. On the other hand, if the lottery were open to all, potential parents who would do well in a screening process might object to competing for the drug against parents they consider "unfit"; they would argue, in short, that "equality" does not always require like treatment of unlike cases. Any scheme of government distribution of Genos will create

267 See note 10 above.

${ }^{268}$ See Shapiro, 48 So. Cal. L. Rev. at 336, 342 (cited in note 10 ).

${ }^{260}$ Calabresi and Bobbitt note the difficulty in designating acceptable distributional criteria. Calabresi and Bobbitt, Tragic Choices at 109 (cited in note 248). Applying such standards will also necessitate expensive, individualized determinations. Id. at 36. Moreover, such personal determinations can exact steep emotional costs from the individual applicants and the entire society. Id. at $37-38,55-61$. 
additional problems. Citizens may object to having their tax dollars spent on the drug or on the particular distribution scheme used. Moreover, any distribution scheme can break down through black markets. ${ }^{270}$ Thus, an outright ban may be the only realistic means of eliminating the threat that Genos poses to egalitarian values.

More importantly, a ban is the only means of eliminating the threat that Genos poses to egalitarian values: even if a "fair" distribution of Genos were possible, the use of the drug still would sharply divide society into Genos and non-Genos classes. To discuss Genos as though wealth differentiation were the only stumbling block is to misperceive the problem. The very existence of such a caste-based social system violates the spirit, if not the letter, of the equal protection clause, as well as that of the thirteenth amendment and the nobility clauses. ${ }^{271}$ This problem inheres even if every potential citizen has a "fair" chance of being a member of the higher caste. ${ }^{272}$

\section{The Philosophical Underpinnings of the Constitutional CoLIISION}

\section{A. Libertarian and Egalitarian Paradigms: Nozick and Ackerman}

The tension that persists between the demands of liberty and equality might stem from ambiguities or limitations in American constitutional theory. Within their respective constitutional spheres, both legislatures and courts can look to moral theory to overcome these limits and formulate legal principle. ${ }^{273}$

270 Id. at 122.

${ }^{271}$ See above at notes 178-79 and accompanying text (nobility clauses), 180-86 and accompanying text (thirteenth amendment), and 196-211, 221-35, 253-61 and accompanying text (equal protection clause).

${ }^{272}$ Even if Genos can be produced at a lesser price and on a larger scale, egalitarian concerns will not be eliminated; they may even be exacerbated. More people will be able to use the drug if it is less expensive, but even though it is free, some may choose not to use it. The position of those few who cannot afford Genos even at a lower price (or those who choose not to use Genos even though they can afford it) will be that of a tremendously disadvantaged discrete and insular minority. The smaller their number, the worse their plight. Thus, wider distribution of Genos through the market-even if Genos people became an overwhelming majority of the population-would not eliminate egalitarian concerns with the drug.

Perhaps even more dangerous than immediate egalitarian problems are the long-term health risks entailed by committing a substantial part-perhaps even the majority-of an entire generation to a new genetic mold about which science knows comparatively little. Even if no harmful side effects have yet appeared, society cannot be sure that none will appear years or generations hence.

273 Examining the precise role of moral principle in judicial decision making travels 
1. Does the Libertarian Paradigm of Robert Nozick Justify Positive Genetic Engineering?

a.) What guidance is found in the values of autonomy, free will, and transcendence?

LIBERTAS: Robert Nozick has eloquently articulated the philosophical underpinnings for the libertarian perspective that would protect Genos. He suggests two justifications for the assertion of individual liberties against the power of the state. The first is the basic human right, founded on free will and constitutive of human dignity, to actualize one's potential. Closely related, the second is the ability to pursue transcendent truth unencumbered by state impediments. Both of these rationales sustain the production of Genos.

Nozick's concept of individual liberty is broad-ranging and rigid: "Individuals have rights, and there are things no person or group of persons may do to them (without violating their rights). So strong and far-reaching are these rights that they raise the question of what, if anything, the state . . . may do."274 The predicate for the "minimal state" 278 that Nozick embraces is his vision of self-actualization nurtured by libertarian values. ${ }^{276}$ State-protected individual autonomy sustains the free will that is central to human dignity and value. ${ }^{277}$ Free will is good not only because it advances the specific value of human dignity, but also because it creates value in a more general sense. Human beings can contribute to value merely by being passive channels for its realization. They can, however, originate value only by an act of free will. When a person originates value, he both engenders greater value for all society and renders himself more valuable. ${ }^{278}$ In Nozick's vision, organisms rank themselves by their relative degree of "organic unity"- that is, how many diverse elements these organisms can discover and comprehend. ${ }^{279} \mathrm{He}$ postulates a sliding scale in

well beyond the scope of this dialogue. For several good discussions of that role, see John Hart Ely, Democracy and Distrust 43-72 (1980); Ronald Dworkin, Taking Rights Seriously 82-88 (1977); H.L.A. Hart, The Concept of Law 55-56, 86-88 (1961).

${ }^{274}$ Nozick, Anarchy, State, and Utopia at ix (cited in note 105).

24 Id.

27 This vision synthesizes seemingly contrary notions of objective morality and autonomy. If objective morality truly exists, it would seem to bind people to it. Nozick, Philosophical Explanations at 354 (cited in note 103).

${ }^{277}$ "Without free will, we seem diminished, merely the playthings of external forces. How, then can we maintain an exalted view of ourselves? Determinism seems to undercut human dignity . . . [and] undermine our value." Id. at 291.

278 Id. at $519-20$.

${ }^{279}$ Id. at $412-17$. "The components of value are diversity and unity. A short hand defi- 
declining order from people to animals to plants to rocks. In this scheme he admits that the value of superintelligent, extraterrestrial beings would exceed the value of humans. ${ }^{280}$

Nozick believes that the superior position of superior beings is deserved. People who are harmoniously ordered beings will inspire everyone. ${ }^{281}$ They also may discover transcendent truths that expand the horizons of the human adventure. ${ }^{282}$ Moreover, because developed people will probably "come to treasure all beings, [they will want] to aid them along a similar path of development to the extent this is possible." esteem because of the superiority of others; they should not measure their self-worth by comparison with more developed people.

Nozick sees no justification for impeding self-actualization and the resulting pursuit of transcendent truth. This pursuit is perhaps the most personal and important endeavor in which one can engage. To subjugate it to countervailing egalitarian claims ${ }^{284}$ is to degrade persons by treating them as means rather than ends-in violation of the Kantian categorical imperative: ${ }^{285}$

To use a person in this way does not sufficiently respect and take account of the fact that he is a separate person, that his is the only life he has. He does not get some overbalancing good from his sacrifice and no one is entitled to force this upon him-least of all a state or government that claims his allegiance (as other individuals do not) and that therefore must be neutral between its citizens. ${ }^{286}$

These rationales of free will, self-actualization, and pursuit of transcendent meaning powerfully buttress acceptance of Genos. ${ }^{287}$

$A E Q U U S:$ Nozick virtually ignores problems of equality in enlisting the minimal state in the protection of the inviolability of

nition is 'organic unity': The more diverse the material that gets unified (to a certain degree) the greater the value." Id. at 416.

280 Id. at 417.

281 Id. at $410,436-40$.

282 Id. at 618 .

283 Id. at 512 .

284 Nozick, Anarchy, State, and Utopia at 235 (cited in note 105).

285 Nozick, Philosophical Explanations at 30-31, 32-33 (cited in note 103).

286 Id. at 33.

287 Parents who can afford Genos should not be deprived of its meaningful reproductive experience. Moreover, parental interests in leaving traces through their offspring should be recognized. Id. at 582-83. Although Nozick does not specifically address the Genos problem, he does endorse genetic engineering and would have the market decide how many pesons in each genotype will exist. Nozick, Anarchy, State, and Utopia at 314 n.* (cited in note 105). 
the person and his property. ${ }^{288}$ Not only does his libertarian theory vindicate economic inequality, but it also justifies inequality of moral worth ${ }^{289}$ that in turn justifies different treatment. ${ }^{280}$ As a result, Nozick's adulation of intellectual development leads to unattractive conclusions. Indeed, his theory could even justify certain forms of slavery, if such slavery would advance the search for the perfection of the few. Slavery would be permissible to Nozick if it resulted from freely made transactions. ${ }^{291}$

Ultimately, Nozick predicates his theories on the admittedly appealing notions of free will and transcendent being. While free will is an important value, it must be constrained by the countervailing claims of others to their freedom and dignity. At some point, denials of equal dignity that subjugate or belittle some human beings for the sake of others in fact violate any realistic notion of liberty. We escape the state of nature and grow civilized only to the extent that we recognize the essential dignity of everyone. ${ }^{292}$ Dignity does not emanate from the free will to starve ${ }^{283}$ or to be genetically inferior in the way that Nozick himself maintains measures human worth. Moreover, the search for transcendent meaning is an elusive pursuit in which the value of certain forms of intelligence is controversial. ${ }^{294}$ In this regard, Genos may be offensive to many people's deeply held beliefs, in particular to certain religious traditions if it does not conform to what they perceive as

283 Id. at ix, 270. Indeed, Nozick even suggests that taxation of wages is on par with "forced labor." Id. at 169.

232 See text at notes 281-86 above.

290 "It may be that at a certain level of someone's development, others ought to treat him in certain ways, yet at a higher level of his development others no longer ought to do so, for their previous behavior could no longer be responsive to his (now) most valuable characteristics." Nozick, Philosophical Explanations at 504. Nozick also says that a superior person cannot demand superior rights, but only that one must change one's behavior toward a superior person in order to be responsive to his identity. Id. at 504.

291 See generally Rawls, A Theory of Justice at 325-26 (cited in note 8). Nozick tries to evade this problem by claiming that developed persons will not enslave others because they will treasure all people and all things. Nozick, Philosophical Explanations at 511-12.

202 Men are, in great measure, what they feel themselves to be, and they think of themselves as they are thought of by their fellows. The advance in individual self-respect and in social amenity caused by the softening of the more barbarous inequalities of the past is the contribution to civilization as genuine as the improvement in material condition.

R. H. Tawney, Equality 171 (1964), quoted in Nozick, Anarchy, State, and Utopia at 348 n.7 (cited in note 105).

${ }^{203}$ Tribe, American Constitutional Law at 573-74 (cited in note 181).

294 For example, see Calabresi and Bobbitt, Tragic Choices at 70 (cited in note 248) (admonishing that logic can be a destructive force). 
divinely ordained rules. ${ }^{295}$ resources?

b.) Can Nozick justify inequalities in the distribution of

LIBERTAS: To the extent that the ethic of liberty itself confines choices, it does so far less than other ethics. Moreover, one need not embrace all of Nozick's libertarian philosophy to protect Genos. The drug implicates very personal decisions about procreation and genetic composition. One might allow widespread economic regulation without countenancing intrusions into this more personal sphere. ${ }^{286}$ While the precise contours of this guarantee of personal liberty may be difficult to define, the guarantee must encompass parents' control over their offspring's genetic makeup. Finally, Nozick's theory provides an answer to the problem of differentiation based on wealth: assuming an equal initial distribution of wealth, subsequent inequalities are justified so long as they result from freely made transfers. ${ }^{297}$ Although Genos may increase inequality in wealth, it does so through free transfers.

AEQUUS: Ronald Dworkin has remarked that Nozick's "starting gate theory" "makes sense in games such as Monopoly, whose point is to allow luck and skill to play a highly circumscribed and, in the last analysis, arbitrary role." ${ }^{298}$ Not only do they exhibit a sense of arbitrariness, but an initial equal distribution of resources and subsequent freely-made transfers are counterintuitive and, in any event, hard to verify empirically. ${ }^{299}$

295 See Paul Ramsey, Fabricated Man, especially 129-51 (1970); Ted Howard and Jeremy Rifkin, Who Should Play God? (1977). In a letter to the President concerning the prospect of positive genetic engineering, three religious leaders admonished " $[t]$ hose who would play God." Letter from Dr. Claire Randall (Nat'l Council of Churches), Rabbi Bernard Mandelbaum (Gen. Sec'y, Synagogue Council of America), and Bishop Thomas Kelly (United States Catholic Conf.), to the President of the United States (June 20, 1980), reprinted in President's Commission at 95-96 (cited in note 10).

${ }^{206}$ See Tribe, American Constitutional Law at 574, 889-93 (cited in note 181). Tribe maintains that one might allow regulation of the free market such as that struck down during the Lochner era and at the same time have broad protection of personal and economic liberty. For him, the error of Lochner was not that it protected economic liberty but that it denigrated true economic liberty by rigidly protecting the free market. Id. at $919,949$.

297 Nozick, Anarchy, State, and Utopia at 150-60 (cited in note 105). Nozick says that any distribution resulting from past injustices may be rectified by governmental redistribution. Id. at 152-53 \& n.*. Indeed, he says that any pattern that does not result from these individual choices can be overturned by these choices. Id. at 164.

${ }^{298}$ Ronald Dworkin, What is Equality? Part 2: Equality of Resources, 10 Phil. \& Pub. Affairs 284, 310 (1981).

200 Nozick specifically countenances government intervention to rectify transfers infected with such coercion. Nozick, Anarchy, State, and Utopia at 152. To the extent that such coercion is empirically verifiable, his "minimalist" state might prove to be extremely active. 
Further, Genos will only exacerbate arbitrary inequalities. The drug increases the dependence of personal liberty on economic resources. Insofar as Genos people will be superior resource generators, they will also be a living form of unfair competition.

2. Does the Egalitarian Paradigm of Bruce Ackerman Legitimate Restraints on Positive Genetic Engineering?

AEQUUS: To buttress a theory of equality that does not denigrate liberty, Bruce Ackerman has formulated the neutrality principle. As his starting point, he postulates the equal worth of every individual. Equal worth requires that any departure from equality of resources be predicated on what Ackerman calls a "neutral justification." That is, to sustain a claim to unequal resources, one cannot assert: "(a) that his conception of the good is better than that asserted by any of his fellow citizens, or (b) that, regardless of his conception of the good, he is intrinsically superior to one or more of his fellow citizens." ${ }^{300}$ On the basis of this theory, Ackerman rejects the creation of any people who could dominate others genetically, because such people could claim inherent superiority. ${ }^{301}$

LIBERTAS: Ackerman's position exemplifies the problems with egalitarianism. First, he assumes that competition for resources is a zero-sum game, that is, that competition is for a finite set of resources. This simply ignores the basic insight of capitalism: that all will gain from free enterprise. ${ }^{302}$ Second, achieving equality of resources is bound to necessitate extensive coercive redistribution: for left alone, free exchanges tend to generate substantial inequality. ${ }^{303}$ Ackerman's theories represent an extreme version of the Aristotelian concept of equality: "things that are alike should be treated alike, while things that are unalike should be treated unalike in proportion to their unalikeness." ${ }^{304}$ This concept is indeterminate unless one defines the categories of morally "alike" and "unalike" objects. ${ }^{305}$ In applying this standard of equality, Acker-

300 Ackerman, Social Justice at 11 (cited in note 69).

${ }^{301}$ Id. at $119-25,133$.

${ }^{302}$ Richard A. Posner, Book Review, 1981 Amer. Bar Found. Research J. 231, 236. See also the "tale of two pies" told by Richard Epstein in Takings: Private Property and the Power of Eminent Domain 3-6 (1985).

sos Posner, 1981 Amer. Bar Found. Research J. at 240-41. Posner argues that the mere assertion of relative goodness hardly comprises a rational basis for receiving an equal share of unequally-distributed goods: under Ackerman's framework, the absence of a rational justification is a neutral reason to deny a claim of equal rights. Id. at 238-39.

${ }^{304}$ Westen, 95 Harv. L. Rev, at 544-45 (cited in note 188), discussing Aristotle, 3 Ethica Nichomachea 1131a-1131b (W. Ross trans. 1925).

${ }^{308}$ Westen, 95 Harv. L. Rev, at 544-45 (cited in note 188). 
man simply defines all human beings as "alike" and thus advocates a draconian state-enforced reordering of societal resources in order to equalize the positions of all human beings. The logic of this position could encompass a claim that government should actively manipulate inherited genetic traits to equalize natural abilities. ${ }^{306}$ From Ackerman's pure egalitarian perspective, Utopia might be a society of clones.

The deepest problems with Ackerman's neutrality principle lie in its assault on societal support for the search for absolute truth and transcendent meaning. If someone can show that her system more closely approximates truth, goodness, or transcendent meaning, Ackerman would not allow her to claim additional societal resources to pursue it. ${ }^{307}$

\section{B. The Ambivalent Rawlsian Synthesis}

\section{Does the Principle of Fair Equality of Opportunity} Proscribe Technologically Inducing Genetic Superiority?

AEQUUS: The intricate philosophical edifice that John Rawls fashioned in $A$ Theory of Justice argues for control of Genos. Rawls's theory moves to counteract "the accidents of natural endowment and the contingencies of social circumstance as counters in quest for political and economic advantage." 308 To mitigate arbitrary inequalities, Rawls seeks to determine how the citizens of a given society would structure the commonwealth if they were ignorant of their individual wealth, abilities, and other resources. ${ }^{\mathbf{3 0 0}}$ He concludes that they would follow two sets of principles. The first set affords all members of society certain basic liberties: "the

${ }^{308}$ If, for example, a hypothetical drug like Genos could be used to correct the deficiencies of the mentally retarded, giving them normal intelligence, Ackerman's equality would seem to dictate its use. Suppose, however, that the use of this hypothetical drug on anyone, including the retarded, would render them nothing less than geniuses. What would Ackerman's equality command in that case?

${ }^{30 z}$ Consider Posner, 1981 Amer. Bar Found. Research J. at 236-39 (cited in note 302).

${ }^{308}$ Rawls, A Theory of Justice at 15 (cited in note 8). Rawls does not contend that the distribution of these abilities is just or unjust. Rather, he claims that this distribution is undeserved. Id. at 103-04. He assumes that the allocation of these abilities is not under direct societal control. Id. at 62 . Genos, of course, negates this assumption. Among the natural abilities listed by Rawls are vigor and intelligence. Id. These are precisely the abilities that Genos, by assumption, augments.

${ }^{309}$ Id. at 16-19. This is Rawls's celebrated "veil of ignorance." It invests his theory with a certain universality because it enables people rationally to choose the society in which they would live without reference to selfish interests dictated by their preexisting societal position. Rawls further argues that, in response to uncertainty, individuals choose according to the "maximin rule": that is, they prefer the least bad outcome among the worst possible outcomes. Id. at 152-53. 
right to vote and to be eligible for public office; . . . freedom of speech and assembly; liberty of conscience and freedom of thought; freedom of the person along with the right to hold (personal) property; and freedom from arbitrary arrest and seizures defined by the concept of the rule of law."310 Because they emanate from the natural rights of each individual, these rights of "equal liberty"311 cannot be abridged for the welfare of the rest of society. ${ }^{312}$

Rawls's second set of principles-subordinate to the first $^{313}$ - concerns the distribution of resources other than personal liberty. Although these principles do not require an equal distribution of income or wealth, they do restrict inequalities of both in certain respects:"314 "Social and economic inequalities are to be arranged so that they are both: (a) to the greatest benefit of the least advantaged, ... . and (b) attached to offices and positions open to all under conditions of fair equality of opportunity."315 The first part of this second set of principles protects the economically least advantaged ${ }^{316}$ and is termed the "difference principle";317 the second part is the principle of "fair equality of opportunity"s18 or "fair opportunity." 118 Just as the principle of liberty cannot be violated to advance either of these distributional concerns, the principle of fair opportunity cannot be abridged to accommodate the difference principle. ${ }^{320}$

Equality of opportunity demands that "positions of authority and offices of command must be accessible to all." ${ }^{\text {s21 }}$ By producing

310 Id. at 61 . Rawls's final formulation of his first principle requires that "[e]ach person is to have an equal right to the most extensive total system of equal basic liberties compatible with a similar system of liberty for all." Id. at 302 .

311 Id. at 204.

312 Id. at 28.

s13 The first principle has absolute priority and cannot be overcome by utilitarian considerations. Rawls allows personal liberty to be restricted only in two narrow cases: "(a) a less extensive liberty must strengthen the total . . . liberty shared by all; [or] (b) a less than equal liberty must be acceptable to those with the lesser liberty." Id. at 302.

314 Id. at 61.

s1s Id. at 302. The second principle even ensures inter-generational equality of opportunity by incorporating a "just savings principle" that requires that the present generation save adequately for the future. Id. at 284-93.

s16 Although the precise definition of "least advantaged" is not critical to the theory, Rawls suggests that the term "least advantaged" might include those with less than one-half of the median income or those in "lower" occupational classes such as unskilled workers. Id. at 98 .

317 Id. at 78.

s1s Id. at 83 .

s10 Id. at 303.

320 See id. at 302-03.

321 Id. at 61. 
such great inequalities in talent-inequalities ultimately tied to wealth-Genos will abridge equality of opportunity without advancing any cognizable interest in liberty as Rawls has defined it. $^{322}$ Consequently, Rawls's reconciliation of the tensions between liberty and equality ${ }^{323}$ requires that Genos be controlled.

2. Does the Difference Principle Favor Positive Genetic Engineering?

LIBERTAS: The poor 'may be helped without placing controls on Genos. Rawls himself acknowledges the tension that humankind's growing ability to improve individual potential poses for his theory, in particular for the difference principle. ${ }^{324}$ Positive genetic engineering is just such a development. Recognizing that society can affect the distribution of natural talents, he says that "[a] caste system, for example, tends to divide society into separate biological populations, while an open society encourages the widest genetic diversity." ${ }^{25}$ While the abhorrence of a caste system reflects egalitarian concerns, the ideal of an "open society" reflects libertarian values. The question in Rawlsian terms therefore is: Does Genos create a caste system or does it advance diversity in an open society?

Genos does not create a caste system. While the drug augments the opportunities of some, it does not segregate society into separate populations. Constitutional rights for all will remain. So will the free enterprise system, which guarantees opportunities for all. The status of Genos people is not preordained: to gain success, they must produce. Spurring production underwrites the difference principle. Rawls himself advocates that people with superior abilities be considered "a social asset to be used for the common advantage." 326 Whether or not Genos people strive to help the least advantaged, the increased wealth, technology, and cultural achievement they generate will benefit everyone. Should none of the wealth benefit the least advantaged, progressive taxation and other redistributive policies can, as Rawls notes, ensure their pros-

${ }^{322}$ Applied to American constitutional theory, Rawls's conception of "liberty" would approximate the explicit guarantees of the Bill of Rights; it does not seem to encompass substantive due process. See text at notes 310-12 above.

${ }^{323}$ Rawls, A Theory of Justice at 204 (cited in note 8).

${ }^{324}$ The tension in Rawlsian theory occurs even under his very narrow conception of liberty, see text at notes $313-23$ above, which does not appear to include childbearing and child rearing interests.

${ }^{328}$ Rawls, A Theory of Justice at 107.

${ }^{326}$ Id. 
perity. ${ }^{327}$ While Rawls is ambivalent about how persons of superior ability might affect the chance for others to pursue their life plans, ${ }^{328}$ this need not be a problem in a growing economy: the discoveries spurred by Genos will broadly expand all people's opportunities. Because Genos can make all people better off, the poor will be better off with it than without it: the difference principle therefore allows production of the drug.

Finally, Rawls might object to Genos on grounds of fair opportunity in the political arena. Admittedly, the superior intelligence of Genos people may secure for them a disproportionate voice in governance. ${ }^{328}$ This problem, however, exposes another tension in Rawlsian theory. Rawls espouses broadly based, democratic rule, ${ }^{330}$ but broadly based rule does not guarantee that the principles of justice will be applied correctly. The superior abilities of Genos people may well sharpen the application of Rawls's own principles.

3. Does the Value of Self-Respect Disfavor Extreme Genetic Inferiority?

AEQUUS: Wealth is not the only important value for Rawls. ${ }^{331}$ Individual and aggregate well-being are functions not only of wealth, but of self-respect and a sense that the world is just and fair. Maximizing wealth within the confines of the difference principle cannot easily be dismissed as undesirable. To do so takes lightly the possibility of improving the position of the least advantaged. The dilemma posed by Genos may be stated as follows: Should society increase the standard of living for the poor at the expense of forever relegating non-Genos people to inferior status, or should it ignore the vital need for additional resources to salvage equality of opportunity?

As formulated, the quandary is predicated on the supposition that some of the extra resources produced by Genos will be redis-

s27 Id. at 278.

${ }^{328}$ Id. at 107. Rational people will respond with gratitude and affection to the strides that Genos people will have made for them. Id. at 494-95.

329 See text following note 203 above.

sso Rawls maintains that in an ideal state representation should encompass all communities of interest and should be drawn "equally from all sectors of society." A Theory of Justice at 228.

ss1 It is a mistake to believe that a just and good society must wait upon a high material standard of life. What men will want is meaningful work and free association with others, these associations regulating their relations to one another within a framework of just basic institutions. To achieve this state of things great wealth is not necessary. In fact, beyond some point, it is likely to be a positive hindrance, a meaningless distraction at best if not a temptation to indulgence and emptiness.

Id. at 290 . 
tributed to the poor. It is far from clear that redistribution will occur. Aldous Huxley's Brave New World contains no difference principle. ${ }^{332}$ The human psyche has a frightening tendency to segregate and subjugate. Genos supplies novel and disquieting sustenance for this tendency: it undergirds the claim of superiority upon which a claim to domination may be predicated. ${ }^{333}$

Rawls recognizes that his difference principle could exacerbate economic inequality if small amounts of benefit to the least advantaged could legitimate large increases in wealth for the best off. ${ }^{334}$ To avert this difficulty, he mandates redistributive institutions of government. ${ }^{335}$ Moreover, he claims that the structure of the just society will itself tend to soften inequality; the difference principle and market forces will broaden opportunities for education and training. ${ }^{388}$ Still, Rawls's solutions may not be sufficient to remedy the inequality that Genos will cause. Education alone cannot easily rectify the differences, in ability that Genos engenders. Even if redistribution does occur, it may benefit groups other than the least advantaged. ${ }^{\text {ss7 }}$

In his calculus of the difference principle, Rawls includes in his measure of benefits other resources besides income and material possessions. These are "rights and liberties, opportunities and powers." 338 A final and perhaps paramount value is self-respect. Self-respect involves thinking that one's life plan has worth and having confidence that one can carry it out. ${ }^{339}$ Self-respect is fundamentally supported by fair opportunity. Non-Genos people will continually witness and compare themselves unfavorably to the superior abilities and accomplishments of Genos people. ${ }^{340}$ That those abilities and accomplishments ultimately derive from

${ }^{332}$ Aldous Huxley, Brave New World (1932). Nor does a difference principle appear in George Orwell's Animal Farm (1946) or Nineteen Eighty-Four (1948).

${ }^{33 s}$ See text accompanying notes $293-94$ above.

334 Rawls, A Theory of Justice at 157-58.

338 Id. at 277-80.

${ }^{336}$ Frequently, training and education will mitigate disadvantages in natural ability by increasing the supply of qualified persons and reducing disparities in pay. Id. at 307.

337 Nozick claims that political incentives prompt more redistribution to the middle class than to the poor. Nozick, Anarchy, State, and Utopia at 274-75 (cited in note 105).

3ss Rawls, A Theory of Justice at 92.

ss9 Id. at 440 . Applying the difference principle, one might argue that Genos will augment all of these primary goods, including self-respect, for the least advantaged. Even if this were true, the principle of fair opportunity for all is prior to, and consequently constrains, the difference principle. See text accompanying note 320 above.

360 Rawls claims that "given our [life plan], we tend to be ashamed of those defects in our person and failures in our actions that indicate a loss or absence of the excellences essential to carrying out our more important associative aims." A Theory of Justice at 444. 
wealth-rather than effort or hereditary luck-may rankle and embitter. Rawls cautions that such emotions can catalyze societal instability. ${ }^{341}$ Although he endorses "intelligence and imagination, strength and endurance," he ultimately concludes:

[U]nless intellect and vigor are regulated by a sense of justice and obligation, they may only enhance one's capacity to override the legitimate claims of others. Certainly it would not be rational to want some to be so superior in these respects that just institutions would be jeopardized..$^{342}$

\section{ConCLUSION}

The dialogue ends here. This is not because the issues are resolved or because one side has triumphed in the argument-that will likely never occur-but because it must end at some point. These philosophical speculations may have little effect on the development of genetic engineering: for better or worse, decisions with the most far-reaching social consequences frequently are made not in open discussion, but in guarded seclusion. ${ }^{343}$ Sometimes, decisions are even made unconsciously, as scientific developments carry people along with them. ${ }^{344}$

To some commentators, the march toward positive genetic engineering is inexorable. Genetic knowledge accumulates quickly from such wide-ranging sources as cancer research, botanical applications, and animal husbandry. ${ }^{345}$ Casting a regulatory net discretely so as not to curb beneficial work such as cancer research ${ }^{346}$

s41 "The most stable conception of justice . . . is presumably one that is perspicuous to our reasoning, congruent with our good, and rooted not in abnegation but in affirmation of the self." Id. at 499.

s42 Id. at 436-37.

34s Often, important societal decisions are not made by government at all, but by persons outside of government. Green, 48 Ind. L. J. at 578 (cited in note 135) ("The decisions to proceed ... are made by small elite groups and are submitted to Congress, for ratification in the appropriations process, without exposition of the basic long-term policy issues."). This decision-making process excludes the voices of nearly all citizens. But see Singer, 3 Yale L. \& Pol'y Rev. at 320 (cited in note 46) ("The more serious dangers of scientific ignorance, however, occur when choices are made at the societal level. At this level, even a single individual can manipulate scientific ignorance and consequent fears into support for irrational, almost primitive myths."). The public may oppose science tampering with the creation of life. Hearings at 181-82 (cited in note 38); Walsh, Public Attitude Toward Science is Yes-But, 215 Science 270 (1982), cited in President's Commission at 29 (cited in note 10).

s11 Green, 48 Ind. L. J. at 574 (cited in note 135).

345 Id.

316 As another example, if a pregnant woman is dying, would society deny her the right to use new technology to have her fetus transplanted into another's womb so that it might survive? Surely not: yet the technology acquired from refining such widely accepted applica- 
will be a delicate task. Some of the genetic advances made in curing disease and other areas will augment knowledge with which to achieve positive genetic engineering. The line between positive and negative genetic engineering is perhaps too elusive for the law to pin down for regulation. Moreover, the legal process may well be unable to cope with these problems with sufficient speed. ${ }^{347}$ The judiciary fashions principles slowly and retrospectively. The legislature, constrained by time, usually tends to the obvious, pressing, and immediate, leaving less concrete concerns for another day. Restraining an area about which we know little risks stifling progress, ${ }^{348}$ yet waiting to regulate until genetically engineered humans exist is unrealistic. After experimental, genetically engineered people exist, it may take a long time and many specimens before we understand their full capabilities and implications. ${ }^{349}$ Once many such people are around, society may not dare to consider the wrenching alternative of telling them that it does not want them. Indeed, the dialogue does not examine whether Genos will affect the germ line so that experimental Genos people could reproduce. Under these circumstances, the options for eliminating the Genos race might be quite repulsive.

Even curbing preliminary research into genetic engineering involves potential first and fourteenth amendment difficulties, ${ }^{350}$ although whatever constitutional right to scientific research may ex-

tions can service more ambiguous enterprises. Gorney, 15 U.C.L.A. L. Rev. at 281 (cited in note 37 ).

347 Senator Gore has cautioned that "genetic technology is advancing so rapidly that it may surpass the ability of our existing institutions to control it." Gore and Owens, 3 Yale L. \& Pol'y Rev. at 338 (cited in note 29).

${ }^{318}$ Green, 48 Ind. L. J. at 574 (cited in note 135).

369 Before a certain stage, scientific development is not sufficiently concrete to frame legislation. Frank P. Grad, Legislative Responses to the New Biology: Limits and Possibilities, 15 U.C.L.A. L. Rev. 480, 481 (1968). It is, for example, important to the formulation of regulatory strategy to identify the line of technological development that ultimately succeeds. Id. at $483-84$.

${ }^{350}$ John A. Robertson, The Scientist's Right to Research: A Constitutional Analysis, 51 So. Cal. L. Rev. 1203, 1251 (1978). Robertson considers the freedom to research critically linked with the freedom to speak, think, and publish. He would place constitutional protection for research under the same degree of protection as freedom to publish: as a prerequisite to regulation, he would require "a high probability" that publication would lead to harm. Id. at 1251. Under this test, government would have difficulty preempting research, since research results are unpredictable and often are not fully understood at first. See also Ira A. Carmen, Cloning and the Constitution (1985) (combining speech and procreation autonomy rights to impose particularly strict protections for fetal genetic research). But see Barry R. Furrow, Governing Science: Public Risks and Private Remedies, $131 \mathrm{~Pa}$. L. Rev. $1403,1412-17$ (1983) (arguing that even pure scientific experimentation is subject to regulation because it is action rather than speech). 
ist surely has limits. ${ }^{351}$ Congress has other alternatives to slow genetic advances: it might circumscribe public funding vital to genetic research or forbid patents on certain products of genetic research, a move that could seriously slow privately funded genetic endeavors. ${ }^{352}$ In addition, Congress probably could force publication of technological processes if it provided advance notice to avoid violating industry expectations. ${ }^{353}$ If business could not protect its formulas, it could not profit from genetic research. To date, however, regulation of genetic research in the United States has been confined largely to containment of risks to health and safety. ${ }^{354}$ Only intermittently have the executive and legislative branches glimpsed the larger philosophical issues. ${ }^{355}$ Against this narrowly focused regulatory backdrop, genetic research is burgeoning. ${ }^{306}$

Whatever one thinks of these developments, they should not be permitted to occur by default of the body politic. The question

${ }^{331}$ See Robertson, 51 So. Cal. L. Rev. at 1278 (cited in note 350); James R. Ferguson, Scientific and Technical Expression: A Problem in First Amendment Theory, 16 Harv. Civ. Rts.-Civ. Lib. L. Rev. 519, 553 (1981); John B. Attanasio, Science and the Constitution, 48 Rev. of Pol. 476, 479-81 (1985) (suggesting four first amendment approaches to regulating scientific research), reviewing Carmen, Cloning and the Constitution (cited in note 350) .

${ }^{352}$ In Chakrabarty, 447 U.S. at 303, the Court allowed genetically engineered bacteria to be patented, liberally construing the statute. Id. at 316 . Thus, Congress would have to amend the patent laws in order to disallow the commercial protection of these products.

sss If the federal government does not explicitly guarantee a trade secret, governmentcompelled disclosure does not constitute a taking in "an industry that long has been the focus of great public concern and significant government regulation." Ruckelshaus v. Monsanto Co., 467 U.S. 986, 1007 (1984).

ss4 Although it reaches some private activities, most federal regulation of pure genetic research focuses on federally funded projects. See generally Coordinated Framework for Regulation of Biotechnology, 51 Fed. Reg. 23,302 (1986). The federal government's current view is that "[a]ny approach to implementing guidelines should not impede future developments in rDNA technology." Id. at 23,308. See also Carmen, Cloning (cited in note 350) (historical and empirical perspective on genetic research); Judith Areen, Regulating Human Gene Therapy, $88 \mathrm{~W}$. Va. L. Rev. 153 (1985) (focusing on federal regulation of human genetic research); John E. Barkstrom, Recombinant DNA and the Regulation of Biotechnology: Reflections on the Asilomar Conference, Ten Years Later, 19 Akron L. Rev. 81 (1985) (asserting that even safety regulations are lax); Marvin M. Quigley and Lori B. Andrews, Human In Vitro Fertilization, 42 Fertility \& Sterility 348 (1984) (outlining state regulations on fetal research); Robertson, 59 So. Cal. L. Rev. at 977 \& n.124 (cited in note 34) (states may not be strictly enforcing their bans on fetal research).

sss For examples of the executive and Congress grappling with the larger ethical questions of human genetic engineering, see Hearings (cited in note 38); President's Commission (cited in note 10); Recombinant DNA Advisory Committee meeting, 49 Fed. Reg. 699 (1984). The government has also resisted funding human gene therapy that might affect the germ line. Recombinant DNA Research, Actions Under Guidelines, 50 Fed. Reg. 9760 (1985).

sss See Lappe, Broken Code at 6 (cited in note 52). Osterfund, Christian Science Monitor, Jan. 14, 1985, at 14, col. 1 (cited in note 28 ). 
is too important to accept passively whatever develops. To choose actively and well, it is important to evaluate the impact of positive genetic engineering on ourselves and our posterity. Because the question defies a strictly rational solution, evaluating it is also valuable in that it exposes the libertarian or egalitarian inclinations within each of us. My own bias is egalitarian. Nonetheless, I cannot claim to have resolved the tension created by potential genetic. research.

The Genos projection only initiates the necessary dialogue. I hope that it clarifies thinking about constitutionally permissible ends and means. Application of this analysis to incremental scientific advances remains. Even for one who believes as I do that something specifically like Genos can and should be banned, individual genetic breakthroughs must be examined on their own merits. In grappling with these perplexing questions, we may learn less about Genos people than about ourselves. 